\title{
INVESTIGATION OF FACTORS CONTRIBUTING TO ACCUMULATION OF SEDIMENTS IN STORMWATER MANAGEMENT PONDS
}

\author{
By \\ Sidra Yasir Siddiqui \\ BEng, NED University, Pakistan 2011
}

\author{
A project \\ Presented to Ryerson University \\ in partial fulfillment of the requirements \\ for the degree of \\ Master of Engineering.
}

Toronto, Ontario, Canada, 2017

(C) Sidra Yasir Siddiqui 2017 


\section{AUTHOR'S DECLARATION}

I hereby declare that I am the sole author of this report. This is a true copy of the project report, including any required final revisions.

I authorize Ryerson University to lend this report to other institutions or individuals for the purpose of scholarly research.

I further authorize Ryerson University to reproduce this project by photocopying or by other means, in total or in part, at the request of other institutions or individuals for the purpose of scholarly research.

I understand that my MRP may be electronically available to the public. 


\title{
INVESTIGATION OF FACTORS CONTRIBUTING TO ACCUMULATION OF SEDIMENTS IN STORMWATER MANAGEMENT PONDS
}

\author{
Sidra Yasir Siddiqui \\ Master of Engineering, 2017 \\ Civil Engineering, Ryerson University
}

\begin{abstract}
The purpose of this study was to investigate factors contributing to sediment accumulation rates in Stormwater Management ponds. For the purpose of this study almost fifty municipalities in Ontario were contacted and in collaboration with five of those municipalities this study was conducted. A questionnaire was developed and sent to municipalities through email and followup with in-person meetings were conducted. After collecting data and analyzing various characteristics of sediment accumulation rates in SWM ponds, a database was developed to systematically record the relevant information. Additional information on pond properties and drainage areas was sought through a questionnaire and meeting with stormwater managers, and supplemented with historic information. Data collected and used in the study was anonymized in all resulting publications. The calculated accumulated rates from the provided data were compared against the values extracted from the literature review. The developed approach will serve in the development of data-driven modelling approach in SWM ponds.
\end{abstract}




\section{ACKNOWLEDGEMENTS}

I would like to thank my project supervisor, Dr. Darko Joksimovic for his guidance, motivation

and direction. I would also like to thank individuals from municipalities A, B, C, D and E for all their assistance. 


\section{DEDICATION}

To my parents and my family for their love and support. To my friends for being themselves. 
TABLE OF CONTENTS

AUTHOR'S DECLARATION____ ii

ABSTRACT__ iii

ACKNOWLEDGEMENTS___ iv

DEDICATION ___

LIST OF FIGURES ___ Viii

LIST OF APPENDICES __ ix

CHAPTER 1: INTRODUCTION ___ 1

1.1 Problem Statement____ 1

1.2 OBJECTIVES___ 3

1.3 SCOPE__ 4

CHAPTER 2: LITERATURE REVIEW ___ 5

2.1 URBAN RUNOFF__ 5

2.2 IMPACTS OF URBAN RUNOFF___ 6

2.3 STORMWATER MANAGEMENT PONDS___ 8

2.4 The Evolution of StormWater Management in ONTARio___ 9

2.4.1 Dry Ponds__ 9

2.4.2 Wet Ponds__ 9

2.4.3 Buildup and Wash off in Storm Water Ponds__ 10

2.4.4 Sediment Accumulation Rates in Ponds___ 11

2.5 INFLUENCING FACTORS___ 13

2.5.1 Hydrologic Data___ 14

2.5.2 Catchment Characteristics___ 15

2.5.3 Storm Water Management Ponds_ 16

2.6 MEASUREMENTS AND MODELLING___ 16

2.7 CONCLUSION AND SUMMARY___ 17

CHAPTER 3: METHODOLOGY___ 19

3.1 SURVEY_L 20

3.2 INTERVIEW _ 22

3.3 DEVELOPMENT OF DATABASE___ 22

3.3.1 Hydrologic Data__ 24

3.3.2 Catchment_L 25

3.3.3 Storm Water Management Ponds___ 26

CHAPTER 4: RESULTS___ 29

4.1 Results OF SURVEY___ 29

4.1.1 Municipality $A+30$

4.1.2 Municipality $B \longrightarrow 32$

4.1.3 Municipality $C \longrightarrow 33$

4.1.4 Municipality D_ 35

4.1.5 Municipality E_ 36

4.2 RESULTS OF INTERVIEW___ 37

4.2.1 Municipality $A \_37$

4.2.2 Municipality $B \quad 38$

4.2.3 Municipality $C \longrightarrow 38$

4.2.4 Municipality D_39 39

4.2.5 Municipality $E_{2} 39$ 
4.3 RESUlTS OF DATABASE

CHAPTER 5: CONCLUSION AND RECOMMENDATIONS

5.1 CONCLUSION

5.2 RECOMMENDATIONS

APPENDIX A - DATABASE 50

APPENDIX B - SEDIMENT ACCUMULATION RATE CALCULATIONS 76

REFERENCES 


\section{List of Figures}

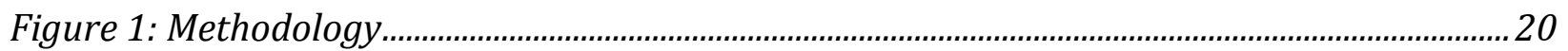

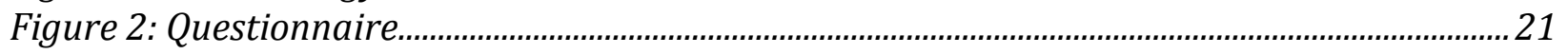

Figure 3: Sediment Accumulation Rates in SWM Ponds............................................................... 44 


\section{List of Appendices}

Appendix A: Database 


\section{CHAPTER 1: INTRODUCTION}

\subsection{Problem Statement}

Urbanization relates to the population or people living in urban area, which results in the physical growth of an urban area. Urbanization is known to significantly increase the rate of runoff and volume, sediment export, erosion, and habitat loss (Wanielista \& Yousef, 1992). The growth in the urbanization and changes in climate impacts increase various factors for example drought and precipitation events, challenging stormwater management in terms of both flood control, runoff control and water quality control. The stormwater that runs from urbanized areas commonly contains a vast range of contaminants including suspended solids, metals and polycyclic aromatic carbons (PAHs) (Westerbeek Vopicka, 2009).

Stormwater ponds (Wet pond, Dry pond, and Wetland) are designed and constructed to partially remove pollutants that flush off of the landscape. Stormwater management facilities (SWMFs), mainly wet ponds, plays a vital role in managing urban runoff and improving water quality for various purposes. Wet ponds, commonly known as detention basins, are designed for capture, hold and treat stormwater through settling with gravity until it displaced by next storm that creates runoff (Hogan \& Walbridge, 2007). A well construct Stormwater pond remove a wide variety of sediment and another non-point source (results from precipitation, land runoff, atmospheric deposition, drainage, seepage or hydrologic modification) pollutant before flowing this water in streams and lakes. A properly designed stormwater pond will clear away a large amount of non-point source pollutants and various sediments from stormwater before discharging this contaminated water downstream. (MOECC, 2003). 
The sediment accumulation within the ponds is both expected and desired, as it shows that SWM pond is performing its function by removing both sediments and pollutants from the urbanization and urban runoff. However, the buildup of sediment decreases the treatment ability in ponds and effluent water quality. In order to meet the increasing pollutants and sediments in storm water ponds and lack of a traditional process to control sediment removal, government regulations require municipalities need to remove the accumulated sediments after a loss of a percentage of design storage volume by using hydraulic or mechanical dredging, which is a very expensive process. To keep preform as designed, SWM ponds requires regular maintenance mainly to eliminate sediment accumulation. As sediment accumulation depends on a number of factors including rain intensity, rainfall duration, construction activities, street-sweeping, storage volume, drainage area characteristics and internal hydraulics. (M Sivakumar \& D.May, 2009).

The performance of SWM ponds is time dependent and steadily decreases as the sediment accumulation rates increase. However, the Stormwater ponds are constructed and designed to collect sediments, but in order to optimize maintenance of the ponds, continuous monitoring is required. SWM ponds are dominated within municipality owned area and it is the responsibility of the city as well as a municipality to clean out the sediment once an SWM pond reaches its required capacity (Randolph, 2003).

Sediment accumulation in Stormwater Management ponds leads to increased risks, including flooding, watercourse health, aquatic life, and erosion. According to the MOE manual, the operational lifecycle of the ponds is fifteen years and the majority of municipalities in Ontario haven't planned any step towards ponds cleanout within their boundary. One way to effectively design, manage and monitor stormwater ponds is to establish a method that can identify a certain amount of sediment removal frequency for an appropriate facility, based on minimizing cost while 
maintaining with government-mandated performance standards. Nowadays, the easiest way of determining the required maintenance time is measuring the sediment levels directly. To predict when the maintenance or repairs are required is the main task as it all depends on how much sediment is accumulated in the ponds, which includes various factors drought intensity, rainfall intensity and duration, construction activities, street-sweeping, storage volume and drainage area characteristics (Ministry of Environment, 2003).

\subsection{Objectives}

The objectives of the project are to develop an understanding of potential factors influencing the sediment accumulation, seeking relevant information from municipalities and developing a systematic approach to organizing the received data. Assemble and organize the information collected from multiple municipalities into a systematic strategy that will allow achieving the desired goal. The results will then communicated back to municipalities, to help in financial planning for cleanouts. The methodology used to determine appropriate sediment accumulation rates for taking a number of factors in accounts, such as local rainfall data, subcatchment characteristics, and detention facility properties, along with the database to investigate the factors contributing accumulation of sediments in SWM ponds. Geographical issues arise when trying to utilize pond data from different areas as sediment, rainfall, and pollutant data can vary significantly depending on location. For these issues, a methodology that can be applied to any facility, regardless of location, was developed. 


\subsection{Scope}

1) The literature was reviewed that includes reports, books, thesis, manuals, journals, articles as well as master plans regarding SWM ponds.

2) Survey Questionnaire was developed based on the literature review that includes all the factors contribute to sediment accumulation in SWM ponds. The questionnaire was sent through electronic email.

3) Interviews were scheduled with municipalities to follow-up of the survey for the collection of data.

4) Development and implementation of the database considering the existing data provided by municipalities during the process of interview.

5) The interest is to compile the information for larger municipalities in which they have more SWM ponds to look after. 


\section{CHAPTER 2: LITERATURE REVIEW}

The effects of urban growth and urban runoff are discussed in this section as they are the primary reasons why stormwater ponds are needed. The main target is on the detention ponds to examine the water quality as well as sediment accumulation in SWM ponds.

\subsection{Urban Runoff}

In today's globally increased and interconnected world, most of the people live in urban areas. The results of several studies show the extreme effect of urban growth on the ecosystem and the environment (Randolph, 2003). The urbanization increases the amount of water that is entering after the storm occurs and reduces the time that it takes water to travel through the stream, lakes etc. Moreover, increasing runoff volume reduces the water that infiltrates the soil texture and recharges the aquifer. Urbanization has the main impact on the natural hydrologic cycle by limiting groundwater recharge, re-routing and channelizing natural waterways, and by increasing runoff, flooding. (Frederic \& Laffont, 2009). It increases the level of the contaminants in water that include insecticides, nitrogen, chloride and polycyclic aromatic hydrocarbons (PAHs) (Coles, 2012). These are the reasons for urban development's main concern nowadays because the urban development is generally contaminated and directly discharges to water bodies, without any treatment processes causing biological, chemical, environmental and physical problems (Coles, 2012).

During the last 50 years, Ontario's urban areas have invested billions of dollars in new treatment facilities to reduce the problem of water pollution. Despite so much of effort, many 
local creeks, ponds and streams are still polluted and cannot use for swimming in Ontario.

(Nittrouer, 1986).

Urban areas have hard, impervious surfaces like rooftops, sidewalks, streets, construction sites and parking areas and pavement that usually collect water and quickly runs off into streams, rivers, and lakes. Contaminants accumulated during dried up periods are gathered by the next rainfall and released to the drainage system. (Wanielista \& Yousef, 1992).

Main pollutants of urban surfaces include motor oils, road salts, animal waste, viruses, bacteria, nutrients, pesticides, heavy metals, thermal pollution and accumulated sediment. (US Environmental Protection Agency, 2003). Most of these pollutants are caused due to human activities that result in continuous deposits on urban surfaces by several wet and dry degradation

processes. In addition to the natural removal of particulates through filtration sedimentation and processes, systems with a biological component can remove soluble pollutants such as oxygendemanding substances, nutrients, metals and organic pollutants through uptake and transformation by plants and bacteria (Robert Abrahart, 2004)

\subsection{Impacts of Urban Runoff}

In the process of nutrient pollution many nutrients, mainly phosphorus and nitrogen are added to water that further act like as fertilizer, and results in too much growth of algae. If it is present in the runoff, nitrogen and phosphorus can cause the process of eutrophication in receiving water bodies (Howarth, 1996). Environments that are enriched with these nutrients even produce toxins that are harmful to life. This can cause problems along the food network (Howarth, 1996) and mainly affects any animal that feeds them. To refrain the harmful effects, developers and city planners should attempt some majors to control the volume of runoff that is coming from new and 
old development by using low impact development, reduce runoff rates, structural control, and pollution prevention approach (M Sivakumar \& D.May, 2009).

As snowmelts and rainfall in various urban areas are further converted into the runoff in urban areas, afterward it transported by drainage watercourses, sewers, streams and finally it discharged to the receiving water as urban stormwater. The other effect of urban runoff is the concentration of suspended solids. The pond that exceeds or meet the design requirements of volume will accomplish its Total suspended (total load of the suspended materials) removal target (Muthukrishnan, 2010). Sources of TSS are much erosion on construction sites and landfill areas, dust in the air, erosion in stream channels by stormwater flows, and fine metals, asphalt, rubber and other particles from roads and vehicles (Robert Abrahart, 2004). Suspended solids that involve in surface runoff leads to water quality, habitat, and problems in urban watercourses. Suspended solids also provide a way for the accumulation, transportation, and storage of several pollutants including nutrients and metals (Glenn \& Doug, 1994). The adverse effect of sediments is usually increased by sorption of particle-bound pollutants as nutrients and metals that make the study of sediments more important. Elevated levels of solids result in increasing of turbidity, reduction of the penetration of light within the water column, and reduction in the growth of aquatic plants (US Environmental Protection Agency, 1998).There are some physical, chemical and biological factors that impact on the urban runoff discussed as below:

- The most common physical factors include sediment (causing destroy in habitat, interference with water quality procedures, impacts on aquatic life, transport of contaminants), flow (the effects of which are flooding, erosion, habitat washout) and thermal energy (causing thermal pollution, deficit of cold water fisheries) 
- Chemical impacts on urban runoff include nutrients (contributing to eutrophication), trace metals, chloride, pesticides, and hydrocarbons (often occurring in complex chemical mixtures in stormwater), Climate change, projected changes in precipitation these are some of the impacts on urban runoff.

- Microbiological factors include microbes like bacteria and viruses of present in stormwater.

\subsection{Storm Water Management Ponds}

Ponds are the structures that are designed for the storage of runoff that is carried from impervious surfaces, advanced infiltration and retain sediment. Stormwater refers to rainfall and heavy snow that melts and flows over the roads, properties, parking lots, lawn and down into the water drains. Monitoring, application and research of best management practices, Stormwater planning and modeling increased the fundamental knowledge about urban development and urban runoff (Barry \& Megan). Stormwater management activities and practices help in minimizing the main impacts of the polluted runoff flowing into lakes and streams (MOECC, 2003).

The ponds which are built before the 1980s were designed to decrease peak flow and some of them don't contain the permanent pool of water. Later, both quality and quantity were consider for designing of the ponds. The permanent pool is also provided with the active storage. This active storage allows time for sediments and pollutants to settle down as water in the ponds is gradually released into nearby streams or lakes. 


\subsection{The Evolution of Storm Water Management in Ontario}

This section mainly describes the history of stormwater management in Ontario, including the construction of wet and dry ponds, maintenance of SWM ponds as well as accumulation rates of sediment are also discussed.

\subsubsection{Dry Ponds}

In the early 1980s, the watershed plans were adopted in Ontario, that includes the Master drainage plan which was most popular due to the matters pertain stormwater runoff (US Environmental Protection Agency, 1998). In that era, floodplain management, runoff quantity control, and erosion/flood control were the main concerns, which further resulting in the construction of dry ponds across Ontario (Wanielista \& Yousef, 1992). These stormwater facilities are end-of-pipe controls, meaning that they remove contaminants that are already formed from the stream of water- urban runoff. Dry ponds do not have a permanent pool of water and temporarily hold stormwater for a few days, slowly releasing to reduce downstream impacts.

\subsubsection{Wet Ponds}

Wet ponds also refer to retention basins, these are man-made stormwater facilities that always contain a permanent pool of water (Wanielista \& Yousef, 1992), and are often located in urbanized areas. In the present era, wet facilities are the most important (MOECC, 2003) and common end-of-pipe stormwater management facility (SWMF) in Ontario (Ministry of Environment, 2003) due to retaining water and their effectiveness in eliminating contaminants from stormwater and peak rate mitigation (Arvind \& Pitt, 2006).

The main benefit of wet ponds is effective pollutant removal, total suspended solids, total phosphorous (TP) and nitrates, elements that usually found in agricultural runoff. This is 
accomplished by holding the runoff in these ponds for significant durations of time, allowing gravitational settling to naturally clarify the water of particle-bound pollutants and sediment (Westerbeek Vopicka, 2009). In regions where nutrient loading into receiving drains is an issue, retention basins can be planted with certain species of vegetation to alleviate this problem (Ministry of Environment, 2003).

There are some key objectives of wet ponds maintenance that includes preventing accumulation of sediments that helps in reducing storage volume, monitor, and maintenance of safe water levels, prevent debris blockage of outlet structure, maintain pipe and riser, protect against invasive plants, ensure structure integrity of the embankment weir and main important factor is maintaining water quality (Randolph, 2003). Due to their various benefits, the implementation of wet ponds is considered as one of the Best Management Practices (BMPs) for controlling stormwater runoff and quality (M Sivakumar \& D.May, 2009).

\subsubsection{Buildup and Wash off in Storm Water Ponds}

The treatment of urban runoff is now well established in various countries and several recent investigations have evaluated. Wet ponds maintain a permanent pool of water as well as detaining Stormwater. The Permanent pool is the major difference between retention and detention ponds. It is designed for water quality treatment with the help of providing a relative amount of storage volume for the settling of the suspended solids and particulate matter that are carried in stormwater runoff. Ponds have internal and external sediment loads. When water enters ponds, sediments on the bottom of the ponds. Organic sediments in ponds originate from plankton; other sources are from several land uses. There are several methods to calculate sediment loads including buildup and wash off. The water quality helps in stimulate generation of buildup TSS from each sub-catchment tributary of the ponds, including pollutant buildup during dry weather periods and 
wash off during rainfall period (Wanielista \& Yousef, 1992). The buildup of total suspended solids that accumulates within each land use category (forest, farm, grass, road salting/sanding practices, bare, catch basin cleaning, street sweeping roof, pervious pavement, impervious pavement, gravel, wetland and water) effects long-term suspended solids removal deficiency. The pollutant buildup is expressed by a rate that increases proportionally by the number of preceding dry weather days until a maximum accumulation mass is achieved (Arvind \& Pitt, 2006). The buildup of the accumulated TSS becomes available for wash off into the collection systems. During wet weather events, these sediments wash off easily. During wet weather events, these concentrations are sustained until the accumulated buildup mass is depleted at which time wash off ceases (Rishon, 2010)

\subsubsection{Sediment Accumulation Rates in Ponds}

The focus of the report is on the sediment accumulation rates in SWM ponds. The main disadvantage of sediment accumulation in SWMPs is reducing of pond longevity and increasing management costs. In many cases, those ponds reached their design capacity in terms of sediment accumulation and required recovery and maintenance for the longer performance (Gollan, 2016)

Stormwater runoff from several sources such as parking lots, highways, open land, rangeland, residential areas and commercial areas can enter in ponds directly as sheet flow. These sources create sediment accumulation in ponds. Excessive sediment loading from these sources is the major cause of sediment accumulated in ponds. Sediment accumulation rates in SWM ponds vary over a wide range, depending on a number of factors related to the catchment area characteristics, precipitation patterns and the pond design and operation, and this is reflected in literature and guidance documents (Richard, 2010). Pond age, depth, layout, water levels, the number of measurement points, catchment, characteristics, size, shape, vegetation and flow 
monitoring are the factors that should be considered when performing sediment accumulation rates measurements. For a sand/gravel inflow, bottom sediments comprised silt and clay, with high water content (up to $80 \%$, by volume), and accumulated at a rate of $0.02 \mathrm{~m} \cdot \mathrm{yr}^{-1}$ (bulk sediment depth) (J.Marsalek \& P.M Marsalek, 1997). Another report also mentioned the sediment accumulation rate is estimated that the rate of accumulation ranges between 0.5 and $2 \mathrm{~mm} \mathrm{year}^{-1}$ (Zalewska, 2014)

Sediment accumulation is the stage pertaining to a decidedly longer period as compared to the first stage which then further results in particle deposition and removal, leading to the preservation of the strata. Accumulation rates have a very simple formulation that is the measure of the thickness of the sedimentary deposit which divides by the time that takes into to elapse between the start and finish of the deposition process. This process eventually results in changes in the thickness and elevation of sedimentary surfaces that standardized in the time variation between the observations (Ministry of Environment, 2003). The MOE recommends that sediment removal occurs, once TSS removal falls more than 5\% below the level of protection established design (Stormwater Management Facility inventory, Assessment and maintenance needs plan Final report, 2008).

Since various approaches have been taken in the past to measure SWM pond sediment accumulation rate, it is important to study and compare them to determine common practices. For determining sediment accumulation in SWM ponds, field measurements are the most recommended and widely used method. Direct measurement is performed by maintenance crews taking the depth of sediment and later converting the data to sediment volume. For calculating sediment accumulation rates, it is a critical task because when applying a theoretical approach, it is obvious that not only should gravitational force be considered in order to calculate the 
sedimentation rate but also other aspects such as eddy viscosity, turbulent diffusion and the grain distribution of suspended sediment are also taken into account (Credit Valley Conservation Ontario, 2010). Accumulation of bottom layer of sediments in the study of SWM ponds was measured by averaging the thickness of top layers above firm soil that is usually collected samples from each pond (Jacobsen, 1994). For sediment accumulation, it is necessary that the permanent pool is sized to provide adequate water quality treatment volume that can achieve a level of protection to provide $80 \%$ of water quality treatment. Several techniques are used to measure sediment accumulation like a boat and staff, Dipstick and Disk, Bathymetry, Stick or Gum spear and Enders and Hauser Device (Mitchell, 2010).

\subsection{Influencing Factors}

According to Stokes Law, sediment with a higher density or larger mean diameter will settle out of suspension faster than smaller particles. Flocculation of fine sediment (less than 63 micrometers) is controlled by sediment geochemistry, particle size/density, water column turbulence (De Boer and Stone, 1999), pH, SS concentration and organic carbon content (G Droppo, E Walling, \& Ongley, 1998).

Several different factors that potentially have an influence on the sediment loading and removal (i.e. accumulation) in SWM ponds. When the sediment is floating within the water column it is considered suspended. Bulk and large sediment loads are the most common issue in SWMPs. Too much sediment accumulation in the pond can cause poor water quality inside and outside of ponds, algal blooms, and deposition build-up. For aquatic life, excessive suspended sediment in the effluent can disrupt aquatic migration in the receiving water, as well damage gills and other organs. The factors contributing to sediment accumulation rates divided into three parts: 
- Hydrologic Data

- Catchment Characteristics

- Storm Water Management ponds

\subsubsection{Hydrologic Data}

There are various components that are prepared to begin the hydrologic analysis. Manual analysis, empirical and model simulations usually have similar requirements as per these components. Components that would be expected for gathering hydrologic data are historical precipitation records, snowfall, and snow melts measurement records, flow monitoring in ponds inlets and outlets, the level of pond monitoring records and records of water quality monitoring at pond inlet or outlet (either grab samples or concerted monitoring campaigns).To investigate sediment accumulation rates, hydrologic data also includes sub-catchment delineation and rainfall inputs generated from synthetic design storms. An excessive amount of rainfall results in increasing of runoff flows and change in sediment loading SWM ponds. The pond will suffer from erosion, instability and sediment accumulation. Hydrologic parameters include imperviousness, infiltration approach, variables required for hydrograph computation, channel routing, and reservoir routing controls ( $\mathrm{Lu}, 2016)$. The main purpose of hydrologic data is to provide the information relating to peak flow rates and volumes, helps in calculating sediment accumulation rates. For example during the rainfall event, most of the Phosphorus load deposited in the bottom of the Pond during the first flush. Almost $80 \%$ of sediments trapped in the pond during the typical rainfall event. (Ellis, 1999).Sediment accumulation reduces the capacity of ponds in Storm events which can lead to flooding that's why pond level monitoring is necessary to reduce sediments. (Coles, 2012). Similarly, flow monitoring and flow monitoring stations are required to reduce sediments in SWM ponds. 


\subsubsection{Catchment Characteristics}

Catchment has long been recognized as the key understanding of the ecology of SWM ponds. Openings along parking lots and curbs from where rainwater will enter the storm sewer network designed to capture heavy contaminant, debris, and grit. Catch basins are usually marked with a fish to remind people that storm water eventually makes its way into nearby waterways (Jacobsen, 1994).

For analyzing sediment accumulation and its rates catchment characteristics are one of measure areas that should be considered. Catchment characteristics includes are the catchment areas to storm water management ponds delineated and if information is available on it, information regarding the road network and storm sewer collection network digitally or manually, information on impervious surfaces (roofs, roads/sidewalks, parking lots, driveways) available, data on land use available (industrial, commercial, institutional, residential high/med/low density), information available on catchment changes since SWM pond was designed (e.g. construction activities) that includes if any historic images are available and their records available for catchment practices: catch basin cleaning, street sweeping, road salting/sanding practices, etc. The changes in landuse, increase in impervious area and evolving of pollutants due to human activity effects the catchment area of the Ponds resulting in the sediment accumulation in SWM ponds. Similarly, catchment practices (catch basin cleaning, street sweeping, road salting, and road sanding practices) increase the pollutants that result in increasing of sediment in nearby SWM ponds. 


\subsubsection{Storm Water Management Ponds}

For investigating accumulation of sediments in storm water ponds information is required like: Have the ponds been characterized according to their design criteria (i.e. dry/wet pond, storage volume capacities, stage-storage curves, area, inlet/outlet structures, number of cells, sediment bay, length/width ratio, permanent pool depth, screening devices at inlet/outlet, etc.), information is available regarding the accumulated sediment (protocol followed in the survey, survey dates and results, sediment characterization, etc.), planting/ maintenance records and if ponds are used for irrigation purposes. As these ponds improve the quality of water the permanent pool within the pond allows sediment to settle down at the bottom before water release the stream. In addition, the areas around the SWM ponds usually contain dense natural vegetation/grasses. This vegetation provided to improve the water quality by helping sediment filtration. In addition permanent pool volume (high and low level) also indicates the accumulation of sediments as when pool levels drop too low, water quality is threatened by algal blooms and anoxic conditions, which can lead to killing fish habitat and plants (Credit Valley Conservation Ontario, 2010).Similarly, a clogged and low flow orifice shows the most common reason in higher than normal permanent pool level. This clogging will decrease the storage volume of SWM ponds which leads to entering of more pollutants through runoff (Stormwater Wet Pond and wetland management Guide book, 2009).

\subsection{Measurements and Modelling}

Stormwater quality and its impacts on the potential receiving waters can be mathematically modeled that will help in treatment requirements in SWM ponds. Some monitoring data are needed to validate such models (Committee, 1999). Various stormwater quality models have been built to predict the performance of treatment measures, each with different assumptions, objectives, and 
applications. (Jesper Persson, Hydraulics efficiency of constructed wetlands and ponds, 2006).They are expected to become significant analysis and modeling tools as the best models can be used to help manage combined sewer overflows, determine which BMPs should be used and where, and prepare impact assessments involving changes in land-use (Christopher \& Josef, 2007).

Stormwater models are categorized as being either deterministic or stochastic. Deterministic models attempt to compete for real processes by using causal relationships, whereas the results rely on past events, while the stochastic models use statistical probability distributions to achieve the common outcomes. Examples of deterministic models include the Stormwater Management Model (SWMM) dynamic rainfall-runoff-routing simulation model, Hydrologic Simulation Program Fortran and Storage, Treatment, Overflow, Runoff Model (STORM) (Christopher C. Obropta, 2007).

The rate and character of accumulated sediments are conditioned, by various factors of natural origin (MOECC, 2003). For modeling, the sediment accumulation rates certain data is required to represent the construction or appearance of deposition in stormwater ponds. Several modeling techniques are used to identify the accumulation rates of sediments e.g. CRS model (Lubis, 2006). Accumulation rates are developed with the help of the measurements of the sediments.

\subsection{Conclusion and Summary}

The purpose of the literature review was to investigate the factors contributing to sediment accumulation rates in SWM ponds. Develop and document an understanding of all the factors that potentially influence sediment accumulation in SWM ponds. Historical precipitation records, records on snow melts, snowfall, flow monitoring at inlet and outlet, pond level monitoring, water quality monitoring at inlet and outlet, catchment areas delineation, storm water 
collection network, impervious surfaces, land use data, catchment changes, catchment practices, as built drawing, information regarding sedimentation depth, accumulated sediment, vegetation, and irrigation all these factors are identified through literature review. Many gaps in the literature are due to data limitations, a large amount of SWM ponds in Ontario are not monitored frequently. This makes the investigation difficult. For example data records often specify the time since the last Pond surveyed for accumulated sediment whereas months or days are preferred in order to preserve accuracy. Additionally, changes in land-use or construction of another stormwater facility within the drainage area will affect sedimentation rates in the pond. 


\section{CHAPTER 3: METHODOLOGY}

This chapter will cover the detail explanation of methodology that used to investigate the factors contributing to sediment accumulation in SWM ponds. Descriptions of all the collected data and the methods used to collect them are also included in this chapter. A schematic figure of the project is presented in Figure 1.

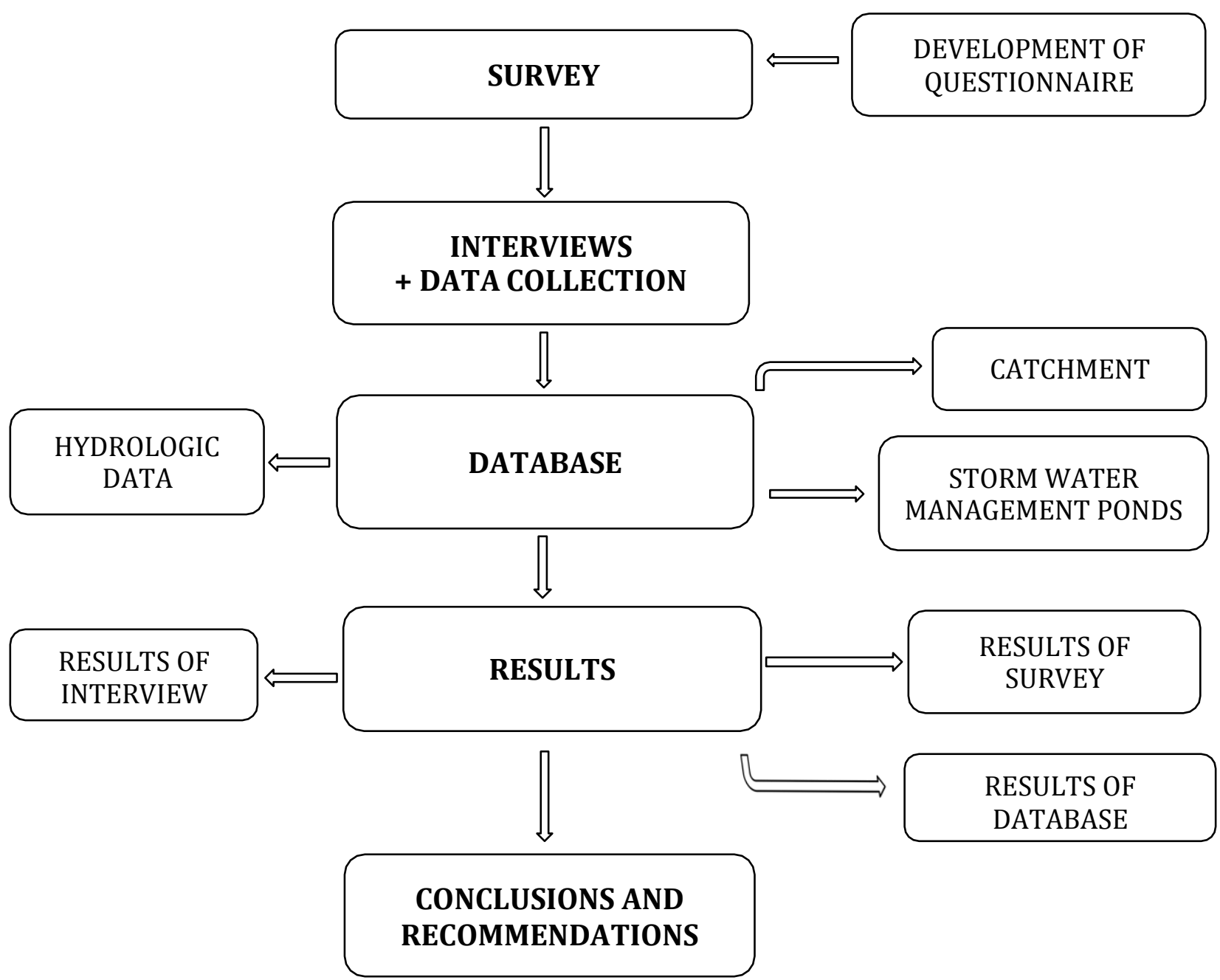




\section{Figure 1: Methodology}

\subsection{Survey}

A well-planned data collection process leads to more orderly and effective analysis. Before collecting any data and contacting municipalities a questionnaire was developed for seeking information from municipalities to help in priorities for stormwater management, drainage practices, and programs in the various cities. In order to gain further knowledge into measurement practices in Ontario, a questionnaire was developed considering all the factors mentioned in the literature review and further divided into three main sections hydrologic characteristics, catchment and storm water ponds. The success of this study is to gather the quality data for sediment accumulation in SWM ponds is highly depend on the support of the municipalities and help in collaborating on this study. The questionnaire contains various components which taken into consideration that helped in investigating the factors contributing to sediment accumulation in SWM ponds and further in the development of the database. The questionnaire was distributed to municipalities using electronic mail. One to one meetings and personal interviews were conducted that gave a chance to seek knowledge about the municipality. Questions regarding measurement techniques used, routine pond survey procedures used by different municipalities, cost, time and the number of personnel used, tools and software for data processing, and suggested improvements was asked in the interviews. All data gathered in the database are used anonymously in this report. Shown in Figure 2 is the questionnaire which helped in collecting data from several municipalities. 


\section{INVESTIGATION OF FACTORS CONTRIBUTING TO ACCUMULATION OF SEDIMENTS IN STORMWATER MANAGEMENT PONDS}

The following questions pertain to different factors that potentially have an influence on the sediment loading and removal (i.e. accumulation) in SWM ponds, grouped into hydrologic, catchment and pond categories.

Hydrologic Data

1. Are historical precipitation records available?

Yes - what duration (YEAR from - YEAR to, MONTHS of the year)and frequency (e.g. 15min, hourly, daily)

2. Is there any records from snowfall and snowmelt measurements?

3. Are there any records of flow monitoring at pond inlet and/or outlet?

4. Are there any records of pond level monitoring?

5. Are there any records of water quality monitoring at pond inlet and/or outlet (either grab samples or concerted monitoring campaigns)?

\section{Catchment}

1. Are the catchment areas to SWM ponds delineated? Is this information available digitally?

2. Are information on the road network and storm sewer collection network available? Is this information available digitally?

3. Is information on impervious surfaces (roofs, roads/sidewalks, parking lots, driveways) available? Is this information available digitally?

4. Land use data available (industrial, commercial, institutional, residential high/med/low density)?

5. Is any information available on catchment changes since SWM pond was constructed (e.g. construction activities)? Are historic aerial images available?

6. Are there records available for catchment practices: catch basin cleaning, street sweeping, road salting/sanding practices, etc.?

\section{SWM Pond}

1. Are pond design or as-built drawings available? Have the ponds been characterized according to their design (i.e. dry/wet pond, storage volume capacities, stage-storage curves, area, inlet/outlet structures, the number of cells, sediment bay, length/width ratio, permanent pool depth, screening devices at inlet/outlet, etc.?)

2. What information is available regarding the accumulated sediment (protocol followed in the survey, survey dates and results, sediment characterization, etc.)? Is this data available digitally?

3. Are planting/ maintenance records available?

4. Are any ponds used for irrigation?

Figure 2: Questionnaire 


\subsection{Interview}

An important aspect of successful study and survey is the adequate distribution of the questionnaire to a wide range of participants. E-mail surveys were sent to the list of municipalities in Southern Ontario. Almost fifty municipalities were contacted, the response of the survey was not satisfactory in the initial stage but afterward due to the shortage of time focus was just those five municipalities that gave the positive response. As Survey questionnaire was designed to facilitate and encourage a larger number of replies. In all possible cases, choices of answers were provided to make the questions easy to answer and to simplify the analysis of the responses and further clarification on the questions were also provided through emails as well as one to one meetings. The data which was collected from those five municipalities was used in this project to achieve the desired objective of developing an understanding of potential factors influencing the sediment accumulation, getting relevant information from municipalities and developing a systematic approach to organizing the received data from municipalities

\subsection{Development of Database}

Once the data has been collected the next step is to compile it in a usable format. The need for accurate and applicable data is the key factor for the development of the database. For the development of the database for sediment accumulation in Storm Water Management ponds, it is necessary that the collection of information is organized so that it can easily be accessed, updated, and managed. To develop a comprehensive database to investigate the trend of several factors that effects the sediment accumulation in the Stormwater Management ponds is very important.

Several factors were included in the database for example type of facility (dry pond, wet pond, wetland), year of construction, maintenance priority (high, moderate and low), hydrologic data (rainguage, records on snowfalls and snowmelts, flow monitoring at inlet and outlet, 
precipitation records, ponds level monitoring, water quality monitoring), catchment characteristics (drainage area, catchment area delineation, storm sewer collection network, impervious surfaces, landuse, catchment changes, catchment practices) and all important features of Stormwater Management ponds (design of the pond, inlet structure, outlet structure, presence of forebay, impervious area, extended detention requirements, total storage volume, length to width ratio, sediment load removed, percentage storage loss, vegetation and planting records) that directly or indirectly plays the role in sediment accumulation in Stormwater management ponds. A review of all available background information was performed to characterize the existing facilities provided by all five municipalities. Master plans, reports, manuals, drawing digital images and spreadsheets were provided by municipalities for all the factors that mentioned in the investigation of the database. The database was populated with data provided by participating municipalities are described below:

- SWM facility numbers were given to each Pond as $1,2,3 \ldots$ As only wet Ponds was considered in the database.

- Year of construction shows in which year the ponds were built as per Master plans or reports.

- Type of facility shows the category of the Wet pond, Dry pond, Wetland and Wetland/Wet pond.

- The Wet facilities classified as a high, moderate and low priority for maintenance.it means priorities was given to the Ponds based on this risk classification (impervious percentage risk score multiply by catchment area risk score). To determine which ponds have the 
highest risk of the combined effects of impervious percentage increases and catchment area increase.

\subsubsection{Hydrologic Data}

- A station used for weather observation at any site from which official weather observations are made. It is normally equipped with instruments like rain gauges for measuring meteorological elements is called as rain gauge station. For each pond, closest rain gauge from the municipality and Environment Canada is observed.

- Precipitation data was collected from all rain gauges using electronic data loggers that measure the rainfall every 15 minutes using either a tipping-bucket rain gage or a collection well gage. Measurement of the precipitation records is the vertical depth of water which reaches to the ground at the stated Point. It is one of the important factors in analyzing the sediment accumulation rates in SWM ponds.

- Continuous flow readings are a reliable indicator of the SWM facility's response to rainfall events and should be measured at the inlets and outlets of the pond, including the emergency overflow outlet.

- The Water level in the ponds recorded from a secure station near the sediment forebay (commission, 2012).Sediment forebay is vital for maintenance and longevity performance of the SWM pond. The bottom of the forebay may be hardened to make sediment removal, so the presence of forbey or not is important for sediment accumulation rates.

- Monitoring for the quality of water in SWM ponds is necessary for the receiving system for the effectiveness of the stormwater management facilities at the location of the outfall. Water quality sampling parameters include Total Phosphorus (TP), Total Suspended Solids (TSS), Temperature and in some cases Dissolved Oxygen and Chloride. 


\subsubsection{Catchment}

- Watersheds refer to catch basins or catchments, are physically delineated by the area upstream from a specified outlet point. Watersheds can be delineated manually using hardcopy maps, or digitally in a GIS environment .catchment area delineation digitally or manually is required for each Pond.

- Storm sewers carry precipitation, rainfall and other surface runoff directly to the nearest creek, stream or river, frequently with sometimes minor or no treatment. These factors take part in preventing pollutants from entering the storm sewer system and damaging the water ecosystem.so that is why it is necessary to get this information digitally or manually for each Pond.

- The Impervious area represents the ratio of area covered by an impervious surface (e.g. asphalt, concrete) to the entire area and also represents the ratio of impervious areas directly connected to the conveyance process. The Impervious area would be a parking lot, a portion of roof areas, driveways, or roads that contain catchbasins draining to the storm sewer and directly connected with Stormwater management ponds. If the SWM block is oversized, there may be adverse effects on the economic viability of the proposed development, and if undersized, there could be negative impacts on adjacent existing properties and homeowners.so, impervious surfaces like roofs, parking lots, driveways and sidewalks should be measured properly as well as land use of these total impervious areas like commercial, residential, industrial, mixed use etc. 
- Catchment changes refer to low risk, medium risk, and high risk. It means as a specific period of time if the catchment area changed due to sediment accumulation in Stormwater management ponds.

- Catchment practices like winter road salting, street sweeping, catch basin cleaning practices and road salting practices plays a vital role in sediment accumulation in stormwater management ponds. Like for road salting there has been growing concern from the scientific community, municipalities, and provincial and federal governments over the use of rock salt (sodium chloride) for winter maintenance and its impact on roadside habitat, crops, aquatic ecosystems and drinking water supplies as it is highly soluble in water so it shows these salts will accumulate in ponds in form of sediments.

\subsubsection{Storm Water Management Ponds}

- As-built drawings for each pond was required which shows all its features like inlet and outlet structure along with other characteristics they are available manually or digitally.

- The permanent pool was sized to provide an appropriate water quality treatment volume based on provincial requirements that achieve an enhanced level of protection presumed to provide an $80 \%$ suspended solids removal rate on an average annual basis.so, it shows permanent pool volume represents how much sediment is accumulated in the specific Pond as typically about $10 \%$ of the volume of the permanent is impeded by the accumulation of organic debris on the bottom of the pond.

- The volume that is provided above the permanent pool is extended detention, which has the various function as per relation with sediment accumulation in Stormwater management Ponds in controlling downstream flows from the higher frequency in the rainfall event. However, extended detention also provides additional water quality 
treatment and streambank erosion protection. This provides extra erosion protection when secondary outfall is clogged due to sediment accumulation and debris.

The Storage volume of the SWM ponds is designed capacity, based on the characteristics of the local storm and rainfall events and the variability of the period between storms. The Storage volume that contributes drainage area and the combination of the permanent pool as well as extended detention storage. The table below shows the MOE SWMP manual design storage volume of water quality as a function of tributary area imperviousness for wetland, dry ponds, and wet ponds.

Stormwater pond Sediment Loading and Accumulation Analysis that a pond that meets or exceeds the required volume will achieve its TSS removal target. The frequency of sediment removal relies on 5\% reduction of TSS removal efficiency or 50\% decrease in the storage volume of the forebay.

TSS which came from erosion of stream banks, erosion from construction sites and dirt from streets, parking lots. Excessive TSS can cloud and harmfully affect watercourses. According to MOE recommends that sediment removal occurs once TSS removal falls more than $5 \%$ decrease from the level of protection established design. (Ministry of Environment, 2003).The 1994 MOE stormwater manual provides Water Quality Storage Criteria determines that minimum storage capacity ( $\mathrm{m} 3 / \mathrm{ha}$ ) required by each wet pond to attain a TSS removal of 5\% less than the TSS removal required by the pond's designated protection level and the catchment area's percent of impervious cover. The currently available storage can be compared to these values to determine the threshold at which the treatment efficiency decreased by $5 \%$. 
For accumulated sediments in Stormwater management ponds the maintenance frequency depends on several aspects, such as the type of facility, design storage volume, characteristics of the catchment area and municipal practices. Sediment accumulation compromises the effective storage volume and the long-term performance of suspended solids retention. For analysis of existing SWM facilities, an inventory method has been established SWM facilities that have been previously identified for retrofit.it further characterize into retrofit, planned retrofit previously and not feasible.it is important to know which year the Pond is planned retrofit and when it surveyed, the results and dates.

Design shape of the SWM pond plays important role in sediment accumulation in ponds where the improper design shape resulting "short-circuiting" and a reduction in pollutant removal efficiency. To maximize removal of contaminant benefits, a long distance between both of the inlet and outlet is needed (a 3:1 or length to width ratio is larger is appropriate). A pond with length to width ratio greater than or equal to $3: 1$ will have an acceptable flow path.

- Vegetation is an integral functional component of stormwater management facilities, contributing to bank stability, pollutant removal and the filtration of stormwater. All vegetation communities should be monitored for health and identify any factors that may contribute to the eventual decline of specific species or the vegetation community that's why it is one of the factors in sediment accumulation in ponds. 


\section{CHAPTER 4: RESULTS}

\subsection{Results of Survey}

This chapter provides an overview of the results of the surveys and interviews for investigation of the factors contributing to the accumulation of sediments in SWM ponds. It's important to have an adequate number of responses from municipalities to come up with accuracy in survey results. The results of the survey are to develop an understanding of potentially relevant data collected from municipalities and to learn how this data is being collected and organized. The reports from each municipality provide the status of the stormwater management facility over the operating year and results of the periodic visits and possible monitoring program. Status of the facility shall be based on Functional and Inspection Monitoring as well as details of any structural modification to the SWM pond. Some participated municipalities conduct regular annual monitoring on the periodic basis, as regular annual monitoring was conducted few years before an SWM pond is assumed by the municipality. So, the results presented in this chapter vary according to the different practices employed by the participating municipality.

As it is already discussed in chapter 3 (methodology) the initial step was literature review as knowledge gained from literature review then utilized to develop the survey. Survey respondents are then interviewed to gain further information into their practices, and data is obtained from them. Varying responses were collected from municipalities. Finally, the data is organized and the database is developed and populated.

After positive reply from few of the municipalities the survey questionnaire was developed keeping in mind all the factors that are contribute to sediment accumulation in Stormwater management ponds. The survey questionnaires were sent to the municipality's resulting in one to one meeting. In between survey it is also discussed that the name of the municipality will be hidden 
in the report so, the five municipalities that are collaborating in this study were named as Municipality A, B, C, D and E and kept as anonymous in report. The data sharing agreement was also signed by each municipality and supervisor for collecting the data of their SWM ponds. For collecting all the data that was the result of the survey, data sharing agreement also signed by each municipality and the supervisor. The results of the survey from each municipality is discussed below in detail:

\subsubsection{Municipality A}

Municipality A is located in Southern Ontario, Canada with the population of 239,900. In response to the survey questionnaire sent to municipality they provided integrated Stormwater Management master plan (ISWM-MP). Municipality A includes one hundred and thirty-two (132) SWM facilities that require regular maintenance (not including natural ponds). According to ISWM-MP on existing SWM facilities the effect of sediment accumulation results in the list of prioritize quality ponds that depends on the decrease in performance and loss of storage. Municipality A grouped SWM facilities according their type (i.e. Dry and Wet Facilities). As the survey questionnaire pertains to different factors that potentially have an influence on the sediment loading and removal (i.e. accumulation) in SWM ponds so after reviewing the ISWM-MP the results of the survey are summarized as follows:

- Precipitation records are available in mm on hourly basis from the Environment Canada.

- There are no records available on snowfall and snowmelt.

- There are no records available on flow monitoring at inlet and/or outlet.

- There are no records available on ponds level monitoring. 
For water quality monitoring the records are available for each Pond. Grab samples are collected and their TSS concentrations are determined at the outlet during the rain event and assessed key visual indicators of Stormwater pollution in Ponds.

The information regarding catchment area are available but only as mentioned in the ISWM-MP, not digitally as catchment boundaries.

Information on the road network and storm sewer collection network available as existing analysis, handwritten surveys and drawings.

Impervious surface (roofs, roads/sidewalks, parking lots, driveways) information is not available.

Land use data (industrial, commercial, institutional, residential high/med/low density) is available digitally as GIS images in ISWM-MP.

Information available on catchment changes since SWM ponds were constructed (e.g. construction activities).

Records for catchment practices: catch basin cleaning, street sweeping, road salting/sanding practices, etc. are not available.

Pond design information is available. SWM ponds were categorize according to their design (i.e. dry/wet pond, storage volume capacities, stage-storage curves, area, inlet/outlet structures, number of cells, sediment bay, length/width ratio, permanent pool depth, screening devices at inlet/outlet, etc.) are available.

The data is available regarding the accumulated sediment (protocol followed in the survey, survey dates and results, sediment characterization).

Planting/ maintenance records available.

None of the SWMP used for irrigation. 


\subsubsection{Municipality $B$}

Municipality B is a town in south-central Ontario with population of 43,517 according to Canada 2011 Census. The study for Stormwater management Ponds in Municipality B proposes for the increase in employment opportunities by creating the Business Park. In the survey, The Town provided a wide range of data that includes existing SWM ponds, existing oil-grit separators and existing storm outfall. Ten (10) wet SWM ponds were inspected in the fall of 2009.The following results of the survey were provided by Municipality B:

- Precipitation records are available in $\mathrm{mm}$ on hourly basis from the Environment Canada.

- There are no records available on snowfalls and snow melts.

- $\quad$ Records available on flow monitoring on inlet and outlet.

- There is no records available on ponds level monitoring.

- For water quality monitoring the records are available for each Pond. Usually they grab sample TSS at the outlet.

- The information regarding catchment area delineation are available.

- Information on the road network and storm sewer collection network available digitally as GIS images.

- Impervious surfaces (roofs, roads/sidewalks, parking lots, driveways) information are not available.

- Land use data (industrial, commercial, institutional, residential high/med/low density) are available.

- Information available on catchment changes since SWM pond was constructed (e.g. construction activities).They categorize catchment changes into low risk, medium risk and high risk. 
- Records for catchment practices: catch basin cleaning, street sweeping, road salting/sanding practices, etc. are not available.

- Pond design are available. Data regarding ponds been characterized according to their design (i.e. dry/wet pond, storage volume capacities, stage-storage curves, area, inlet/outlet structures, number of cells, sediment bay, length/width ratio, permanent pool depth, screening devices at inlet/outlet, etc.) are available.

- The data is available regarding the accumulated sediment (protocol followed in the survey, survey dates and results, sediment characterization).

- Planting/ maintenance records are not available.

- None of the SWMP used for irrigation.

\subsubsection{Municipality $C$}

Municipality $\mathrm{C}$ located in Greater Toronto Area in southern Ontario. Its population is estimated 342,000 through The Region of York population census data monitoring. In response to the questionnaire they provided a bulk of data including GIS images, design briefs, shape files for catchment, sediment volumes and elevation volumes for each Pond. They provided values for 2016 where they are doing surveys as they are available. The following results of the survey were provided by Municipality C:

- Precipitation records are available in $\mathrm{mm}$ on hourly basis from the Environment Canada. 5 minute or hourly duration available depends on area.

- There are no records available on snowfalls and snow melts. According to them their rain gauges are heated.

- $\quad$ Records available on flow monitoring on inlet and outlet.

- There is no records available on ponds level monitoring. 
For water quality monitoring the records are available for each pond. Usually they grab sample TSS at the outlet.

The information regarding catchment area delineation are available.

Information on the road network and storm sewer collection network available digitally.

Impervious surfaces (roofs, roads/sidewalks, parking lots, driveways) information are not available.

Land use data (industrial, commercial, institutional, residential high/med/low density) are available.

Information available on catchment changes since SWM pond was constructed (e.g. construction activities).They categorize catchment changes into low risk, medium risk and high risk.

Records for catchment practices: catch basin cleaning, street sweeping, road salting/sanding practices, etc. are not available.

Pond design are available. Data regarding ponds been characterized according to their design (i.e. dry/wet pond, storage volume capacities, stage-storage curves, area, inlet/outlet structures, number of cells, sediment bay, length/width ratio, permanent pool depth, screening devices at inlet/outlet, etc.) are available.

The data is available regarding the accumulated sediment (protocol followed in the survey, survey dates and results, sediment characterization).

Planting/ maintenance records are not available.

None of the SWMP used for irrigation. 


\subsubsection{Municipality D}

Municipality D has located in southern portion of York region Ontario, Canada. It is the 28th most populous municipality in Canada with the population of 185,541 . The municipality has 96 SWM ponds, of which 50 ponds are wet offline ponds. In response to the questionnaire they provided with the fewer amount of the data which includes only two Ponds but they are positive in further correspondence in this study. The provided data includes AutoCAD drawings, the water level of each Pond in the year 2011 to 2016 and sediment surveys. The following results of the survey were provided by Municipality D:

- Precipitation records are available in $\mathrm{mm}$ on the hourly basis from the Environment Canada. 5 minute or an hourly duration available depends on the area.

- There are no records available on snowfalls and snow melts.

- $\quad$ Records available on flow monitoring on inlet and outlet.

- There are few records available on Ponds level monitoring for newer SWMP. Data need to be confirmed.

- For water quality monitoring the records are available for each pond. Partially data are available for some newer and older Ponds which includes recent data from the year 20102015.

- The information regarding catchment area delineation is partially available. It is only available in PDF format in terms of drawing or design report Sub-watershed catchment areas have been mapped and digitized.

- Information on the road network and storm sewer collection network available digitally.

- Impervious surfaces (roofs, roads/sidewalks, parking lots, driveways) information are not available. 
- Land use data (industrial, commercial, institutional, residential high/med/low density) are available.

- Information available within the area of newer built ponds on catchment changes since SWM pond was constructed (e.g. construction activities). Historical images available of 2009, 2013, 2015.

- Records for catchment practices: catch basin cleaning, street sweeping, road salting/sanding practices, etc. are available.

- Pond design is available. Data regarding ponds been characterized according to their design (i.e. dry/wet pond, storage volume capacities, stage-storage curves, area, inlet/outlet structures, the number of cells, sediment bay, length/width ratio, permanent pool depth, screening devices at inlet/outlet, etc.) are available.

- The data is available regarding the accumulated sediment (protocol followed in the survey, survey dates and results, sediment characterization).

- Planting/ maintenance records are not available.

- None of the SWM ponds used for irrigation.

\subsubsection{Municipality E}

Municipality E is the city of southwestern Ontario, Canada. Its population is 121,688 according to 2011 census. In response to the survey, the questionnaire sent to municipality they provided with the suggestion of meeting with them which will further help in the study. Municipality E did not fill the questionnaire, but according to the response of the questionnaire they sent an email in which they mentioned the availability of data. In the electronic email response, they mentioned the availability of data for precipitation records, pond monitoring, flow monitoring, water quality monitoring, catchment areas, impervious surfaces and SWM ponds. 


\subsection{Results of Interview}

\subsubsection{Municipality A}

The main focus of the report is on the wet SWM ponds, the primary purpose of wet facilities is sediment retention. The methodology applied as part of this project was designed to investigate the factors contributing sediment accumulation in City owned and operated SWM facilities in each Municipality. After the survey, the interview was conducted to gather all the data. According to Municipality A, the analysis of the wet facilities consisted of an estimate of their existing operational efficiencies based on the volumetric water quality criteria and also considering the influence of the accumulated sediment. A Number of facilities analyzed were sixty-one (61), Out of those 61 SWMP Twenty-three (23) facilities were recently cleaned-out or retrofitted. The remaining ten (10) SWM ponds are waiting for the implementation of the planned retrofits. Due to the data gaps Fourteen (14) facilities presented incomplete results, because good quality and enough data allow identifying the sources and causes of sediment accumulation. Incomplete results show either the ponds were not surveyed for that specific factor or not sufficient quality to enable sufficient decisions. For Municipality A, in many cases, the permanent pool is almost or completely full of sediment, directly affecting the effectiveness of the facility in terms of water quality.

The existing street sweeping and leaf collection programs already reviewed, as well as a detailed assessment of catch-basin sediment quality was conducted. They also mentioned that a separate document entitled Integrated Stormwater Management Master Plan (ISWM-MP) Implementation Plan (2016) has been prepared and is included under separate cover. The interview results show a series of short and long term maintenance tasks to be undertaken in near future. 


\subsubsection{Municipality B}

The result of interview helps in the understanding of existing SWM ponds and explore opportunities for future retrofits to improve the performance of overall drainage system. They also provided the information regarding the wet SWMP that were visually inspected and photos were taken during the survey. According to Municipality B, the depth of the water level was also measured in each pond with the help of grid points. The sediment sampling program was also conducted for characterizing the sediments. Core sampling method was used for the collection of the sediment sample. It was also mentioned in the interview that the results of the sediment sample show that two of the facilities contain chemically impacted sediments that should be classified as waste and it needs to be disposed at a licensed waste disposal facility. All the data was provided including the certificate of approvals.

\subsubsection{Municipality C}

The wide variety of data was provided by Municipality $\mathrm{C}$ which includes spreadsheets, GIS images, and reports regarding their work on SWM ponds. They also calculated sediment volume estimates which include estimated \% Full and Actual \% Full. For estimated \% Full they used very simple average and area method to estimate sediment volumes from the information that is provided in the design drawings and one representative elevation from the sediment volume surveys that are

performed periodically. There are several issues with this method, but they found that it gives us a relative idea of the $\%$ full with a minimal amount of work (once the base information is entered, the calculation can be done in less than 5 minutes). For Actual \% Full, they take volume analysis using CAD, comparing original to design surfaces. There are issues with this method as well (related to the quality of the base information available when the calculation was performed), and so we have noticed mistakes in these calculations in the past. This method is 
more reliable according to Municipality $\mathrm{C}$. They also mentioned in the interview that they will be providing values for 2017 where they are doing surveys right now and as results are available and it is expected to be closer to an end of the summer.

\subsubsection{Municipality D}

The results of the interview with Municipality D they provided the data for two ponds that are wet facilities. For precipitation records they mentioned that in the 2003-2009 period, frequency improves over year range from just total rainfall to timed intervals, present rainfall records could be made available until July 2017. According to Municipality D most ponds underwent a recent bathymetric survey between the year 2013-2015 with several ponds undergoing water quality monitoring or sediment sample testing. Results are all available digitally in either MS Excel or PDF format. For snow melts or snowfall records they mentioned to consult with the relevant Conservation Authority or Environment Canada for any data that may be available. In the end of the interview, they mentioned that due to lack of staff they are not able to provide a wide amount of data for now but they are positive to collaborate in this study in future as they are working actively in their SWM ponds.

\subsubsection{Municipality E}

The results of the interview with Municipality E provided with the data sharing agreement and afterward creating a google drive in which they shared all the data regarding their SWM ponds. They provided the data of twenty-eight (28) wet facilities. The data includes files of the catchment areas, maps, reports, sediment depth surveys in 2008 and sediment depth surveys in 2014.Municipality E also mentioned that each facility was surveyed with the help of GPRS and total station to obtain sufficient elevation to estimate Pond volumes, sediment depths, and sediment 
volumes. They also did a lot of work that focused on identification of functional defects for each

SWMP that can be rectified through continuous maintenance work.

\subsection{Results of Database}

The database is the tool for the researcher and stormwater managers that can easily be organized, accessed, managed and updated. The detailed results are provided in Appendix A that shows the outcome of the methodology starting with the development of questionnaire following with survey and one to one interviews and resulting in the database. The database shows in Appendix A includes all the factors that contribute sediment accumulation in SWMP from Municipality A, B, C, D and E. Municipalities were asked to provide the data for each Pond in their area. The overall result of the database as per precipitation shows that almost all of the events have the rainfall amount associated with the monitored event. All municipalities' records precipitation through the gauging stations or weather station for each Pond. None of the information is available on snowmelts and snowfalls by any municipality. Flow monitoring at inlet and outlet are observed by Municipality B, C and E. A sediment survey using the disk/rod technique is common practice by every municipality. Pond level monitoring and water quality monitoring at inlet and outlet records are available for each Pond. In addition catchment area was calculated by all municipalities but none of them records catchment area delineation either digitally or manually. While it was generally acknowledged that some ponds within the municipality's jurisdiction will be approaching their designed capacity within the next three to five years, only three municipalities reported planned clean-out projects and only four are executing cleanouts at regular intervals. A Wide variety of data shows the presence of accumulated sediments in each Pond but many ponds are likely not being cleaned even after they are no longer effectively removing sediment. None of the data is available for catchment practices like street sweeping, 
road salting and catch basin cleaning. Similarly, no data is available for planting records or if the Pond use for irrigation purpose. The overall database shows that the Municipality A, B, C, D and E already implemented regular monitoring programs for some of their Ponds. In an interview, few municipalities also mentioned they are eager to improve their capability to maintain and operate SWM ponds within their jurisdictions. 


\section{CHAPTER 5: CONCLUSION AND RECOMMENDATIONS}

\subsection{CONCLUSION}

The activities related to management of SWM pond sediments have increased in Southern Ontario, and a large number of pond surveys have been completed in recent years. Some municipalities have performed multiple surveys of their ponds a few years apart, in an effort to gain a better understanding of the sediment accumulation rates, however, this practice has not been widespread. Sediment accumulation rates in SWM ponds vary over a wide range, depending on a number of factors related to the catchment area characteristics, precipitation patterns and the pond design and operation, and this is reflected in literature and guidance documents. The purpose of the study was to investigate factors contributing to sediment accumulation in SWM ponds. This chapter summarizes the conclusions from each of the previous chapters to provide a set of cohesive conclusions.

In order to investigate the functional relationship between influencing factors and sediment accumulation rates in SWM ponds, an investigation of data relevancy and availability, as well as organization of data into a usable format is necessary. In this project, a questionnaire was developed based on the literature review that addressed the factors influencing in the accumulation of sediments. After that, the questionnaire was sent to the municipalities, a followup with interviewing the stormwater management staff and collecting all relevant data, which was provided in a variety of formats. The success of the project relied on obtaining a large amount of data and the number of municipalities who wanted to contribute in this study. The data collected was organized in the database shown in Appendix A, so the information is collected and organized will easily be accessed, managed and updated. The database also shows some minor data gaps since it had not been collected by the municipality. The results of this project, in the form of this 
report and the database, are intended to aid future studies. One specific study from the literature review identifies if the average sediment volume of SWM pond is $47 \mathrm{~m}$, which results in an accumulation rate of $1.3 \mathrm{~m} 3 / \mathrm{ha} / \mathrm{y}(\sim 18.7 \mathrm{ft} 3 / \mathrm{acre} / \mathrm{y})$ for the period of April through October. (Gregory, 2014). The conclusion drawn from literature review, the annual sediment accumulation rates in winter period is $2.6 \mathrm{~m}^{3} / \mathrm{ha} / \mathrm{y}\left(37.4 \mathrm{ft}^{3} / \mathrm{acre} / \mathrm{y}\right.$ ) (Gregory, 2014). As The annual sediment accumulation rate can be calculated by,

$$
\text { Annual sediment accumulation rate }=x /(\mathrm{yr} \cdot \mathrm{a})\left(\mathrm{m}^{3} / \mathrm{ha} / \mathrm{y}\right)
$$

Where, $\mathrm{x}=$ Specific component (Sediment Volume) $\left(\mathrm{m}^{3}\right)$

yr. $=$ Number of years $\mathrm{a}=$ drainage area of SWM ponds (ha)

The conclusion drawn from data analysis shows the data collected from Municipality A, B, C, D and E presented in Appendix A. While the calculations of the annual sediment accumulation rates in SWM ponds in Municipality A, B, C, D and E presented in Appendix B. In Other case studies of SWM ponds in Ontario show average sedimentation rates between 0.2 $\mathrm{m} / \mathrm{ha} /$ year and $5.8 \mathrm{~m} / \mathrm{ha} /$ year (Greenland International Consulting Inc, 1999). Data from all municipalities show the average sediment accumulation rates in years (1983 to 2013) between 2.38 $\mathrm{m}^{3} / \mathrm{ha} /$ year and $9.90 \mathrm{~m}^{3} / \mathrm{ha} /$ year, the accumulation rates are significantly higher than those reported in the literature previously in Chapter 2. Blank spaces in Appendix B show data gaps that's why the calculation represents zero value in those data gaps. 


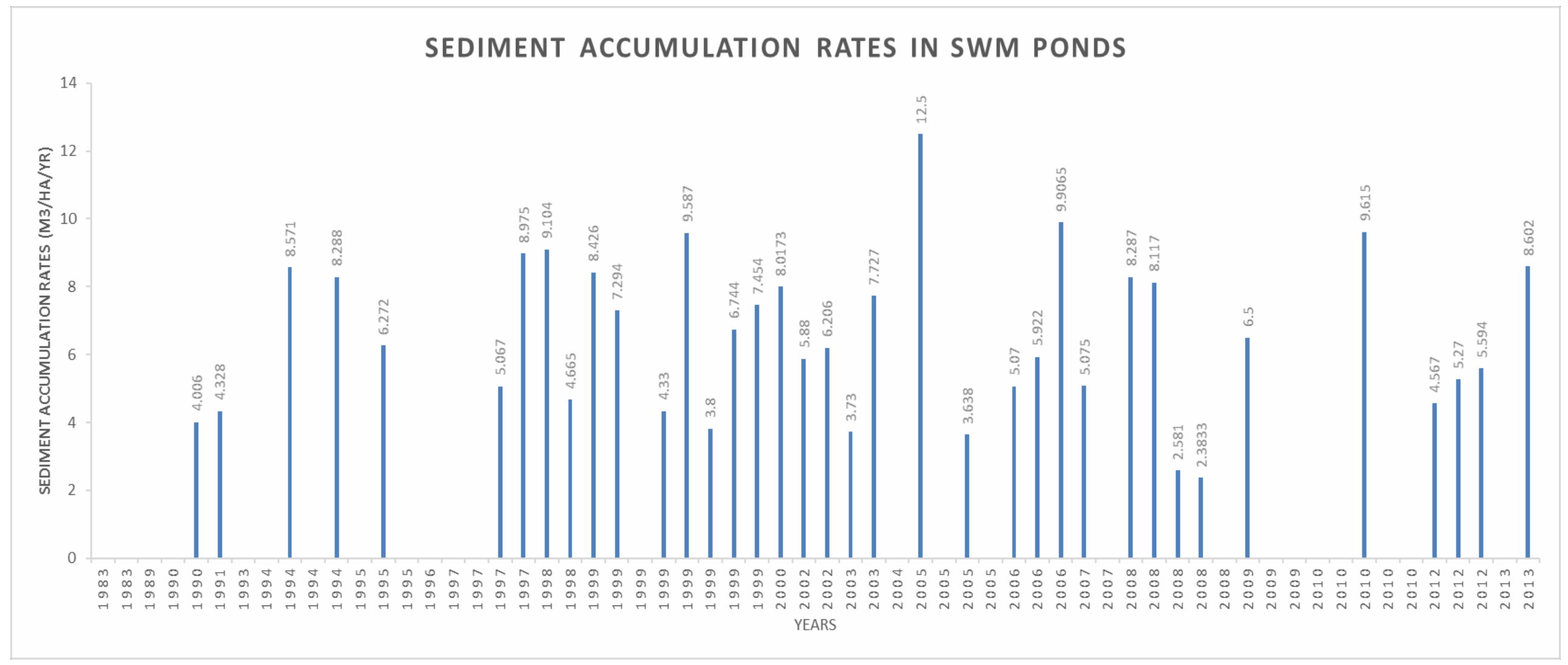

Figure 3(Sediment Accumulation Rates in SWM Ponds) 
The graph above provide the set of decision making for the sediment removal sediment accumulation inspection and clean out frequency. The results from the graph show that some of the SWM ponds in the municipality the accumulation rates are significantly higher than those reported in the literature previously. Results from the graph shows lack of pond cleaning may cause damages like flood or excessive sediment accumulation if the pond storage capacity is sufficiently reduced. As indicated in LSRCA requirements for erosion and sediment control submission highlights the active storage component is to be sized to provide a minimum storage of $125 \mathrm{~m} 3$ / ha with a minimum 48 hour drawdown time and a minimum 4:1 length to width ratio. If the minimum 48 hour drawdown time and the minimum 4:1 length to width ratio cannot be met, then an active storage volume of $185 \mathrm{~m} 3$ / ha will be required. All temporary sediment controls are to provide appropriate outlet protection. It shows that temporary sediment should have a contributing area no more than 10 ha. Results clearly show municipalities prioritize flood control over water quality improvement and control.

The results show from the database, the lack of water quality data, rainfall records and clean out of sediment reports. As mentioned in the interview by Municipality $\mathrm{C}$ lack of the rainfall data is available in winter season as it is a standard practice to remove rain gauges between November and April. On average, $34 \%$ of catchment rainfall appeared as surface runoff during storm events over the monitoring period. Storms with less than $4.0 \mathrm{~mm}$ of rainfall produced negligible runoff, probably due to depression storage and infiltration in roadside ditches. This observation approaches the $5 \mathrm{~mm}$ level suggested in the Ontario Stormwater Management Practices and Planning (SWMP) manual for stream baseflow maintenance (Stormwater Management Facility inventory, Assessment and maintenance needs plan Final report, 2008).Several numbers of findings were made in this study. Data of the extended detention 
requirement, total sediment load removed, sediment volume and design TSS removal highlight the important of SWM ponds inspection and monitoring of ponds inlet and outlet structure.

Since early 1980s street sweeping and various catchment practices provided effective means of moving pollutants and debris from the streets of impervious areas causing sediment accumulation in ponds with the help of urban runoff. Results from database shows municipalities should focus more on catchment practices as sweeper picks less than 63 microns particles that are more contaminated (Gregory, 2014).

\subsection{RECOMMENDATIONS}

This section proposes a number of recommendations that would be beneficial to the advancement of data organization and collection of factors that contribute sediment accumulation in SWM ponds. The major goal of this project is to provide recommendations to researchers, managers and regulators for the development of the systematic approach as the database that includes all the factors contributing to sediment accumulation in SWM ponds.

The literature review recommends a forebay design to remove particles 150 micro metres and larger and enough forebay storage should provide to allow 10 years of sediment accumulation. It is recommended to remove sediment accumulated from the forebay follow up with the field measurements is required in SWM ponds (Greenland International Consulting Inc, 1999).

The study recommends increasing continuous water quality monitoring at inlet and outlet in SWM ponds. Municipalities need to perform more sediment surveys, along with the monitoring of continuous precipitation records through rain gauges at the location of SWM pond. 
In addition, it is also recommended that more records should be measured hourly, monthly and yearly basis, even in winter months if possible. To protect human health and environment, the scope of stormwater management must include the quality of water discharged to the environment.

It is recommended the municipality should monitor the water quality both at inlet and outlet in SWM ponds. Pond cleaning and sediment accumulation monitoring programs currently implemented by municipalities needs to be more advanced design to improve stormwater quality and meet current erosion control objectives, while maintaining its original quantity control function. Overgrown vegetation quantifies the reduction in the pond capacity and also affects the sedimentation process. In fact, it is also mentioned by Persson and Pettersson (2009), vegetation is one of the important factor that contributes to sediment accumulation in SWM ponds that was neglected by all municipalities. Interview identifies the absence of experience in all municipalities. Few municipalities contacted have executed projects to clean at least one SWM facility. Some ponds in municipalities jurisdiction will be approaching their designed capacities within next four to five years. It is recommended in the absence of digital monitoring system manual surveys should planned before cleanout, after cleanout and on the regular basis. Similarly, development of advanced computer software system need to install for permanent sediment monitoring in SWM ponds so it can easily determine whenever the ponds requires sediment removal. More data should be collected by municipalities on factors like the elevation of the ponds, presence of forbey, water quality at both inlet and outlet, sediment forecasting and pond infrastructure is required.

It is also recommended the consultation plan should be developed by the municipalities in their study processes focused on various processes to obtain the public input and residents participation. The public open house should arrange to share community vision and ideas to aware and educate them that will further help in reducing sediment accumulation rates in SWM ponds. 
Results identify more SWM ponds need to be monitored by the municipalities for monitored storage loss, flow monitoring, which will further help in the investigation of sediment accumulated in SWM ponds. Looking forward, few initiatives by municipalities represent the eager of improvement of sediment accumulation in SWM ponds in their jurisdiction. 


\section{Appendix A - DATABASE}

\begin{tabular}{|c|c|c|c|c|c|c|c|c|}
\hline \multirow{3}{*}{$\begin{array}{l}\text { CATCHMENT CHANGES: data } \\
\text { was analysed } \\
\text { to determine which ponds } \\
\text { have the highest risk from the } \\
\text { combined effects of } \\
\text { impervious } \\
\text { percentage increases and } \\
\text { catchment area increases }\end{array}$} & $*$ & $\mathrm{~N} / \mathrm{A}$ & DRY POND & 1 & HIGH PRIORITY & 1 & PLANNED & 1 \\
\hline & 1 & yes & WETPOND & 2 & MODERATE PRIORITY & 2 & PREVIOUSLY & 2 \\
\hline & 2 & no & WETLAND & 3 & LOW PRIORITY & 3 & NOT FEASIBLE & 3 \\
\hline LOW RISK & & & & & 1 & & & \\
\hline MEDUIM RISK & & & & & 2 & & & \\
\hline HIGH RISK & & & & & 3 & & & \\
\hline STORAGE VOLUME CAPACITY & & & & & 1 & & & \\
\hline STAGE-STORAGE CURVES & & & & & 2 & & & \\
\hline STORM WATER PONDS AREA & & & & & 3 & & & \\
\hline NOT REQUIRE MAINTAINENCE & & & & & 4 & & & \\
\hline Rain gauge & & & & & & & & \\
\hline
\end{tabular}


Municipality A (2010-1983)

\begin{tabular}{|c|c|c|c|c|c|c|c|c|c|c|c|c|c|c|c|c|c|c|}
\hline SWM FACILITY\# & 4 & 17 & 21 & 22 & 26 & 30 & 32 & 36 & 37 & 41 & 42 & 43 & 47 & 54 & 56 & 60 & 61 & 66 \\
\hline YEAR OF CONSTRUCTION & 2010 & 1998 & 1990 & 2010 & 2003 & 2013 & 1994 & 1994 & 1995 & 1997 & 1995 & 1996 & 1997 & 2009 & 1998 & 1995 & 1983 & 1983 \\
\hline \multicolumn{19}{|l|}{ TYPE OF FACILITY } \\
\hline \multicolumn{19}{|l|}{ DRY POND } \\
\hline WET POND & 2 & 2 & 2 & 2 & 2 & 2 & 2 & 2 & 2 & 2 & 2 & 2 & 2 & 2 & 2 & 2 & 2 & 2 \\
\hline \multicolumn{19}{|l|}{ WETLAND } \\
\hline \multicolumn{19}{|l|}{ WETLAND/WETPOND } \\
\hline \multicolumn{19}{|l|}{ MAINTAINENCE PRIORITY } \\
\hline HIGH PRIORITY & 1 & & & & 1 & & & & & & & & & & & & & \\
\hline MODERATE PRIORITY & & & 2 & & & & & & & & 2 & 2 & & & & & & \\
\hline LOW PRIORITY & & & & 3 & & & 3 & & & & & & & & & & & \\
\hline \multicolumn{19}{|l|}{ HYDROLOGIC DATA } \\
\hline \multicolumn{19}{|l|}{ CLOSEST ENVIRONMENT RAINGUAGE } \\
\hline FROM MUNICIPALITY & $\mathrm{RG1}$ & RG3 & $\mathrm{RG1}$ & RG1 & $\mathrm{RG1}$ & RG1 & RG1 & RG1 & RG3 & RG3 & RG4 & RG4 & RG1 & RG1 & RG2 & RG2 & RG2 & RG2 \\
\hline FROM ENVIRONMENT CANADA & S07 & S07 & S07 & S07 & S07 & S07 & S07 & S07 & S07 & S07 & S07 & S07 & S07 & S07 & S07 & S07 & S07 & S07 \\
\hline \multicolumn{19}{|l|}{ PRECIPITATION RECORDS(mm) } \\
\hline HOURLY & 32.4 & 30.8 & 32.4 & 32.4 & 32.4 & 32.4 & 32.4 & 32.4 & 30.8 & 30.8 & 31.6 & 31.6 & 30.8 & 30.8 & 18.6 & 18.6 & 18.6 & 18.6 \\
\hline \multicolumn{19}{|l|}{ DAILY } \\
\hline \multicolumn{19}{|l|}{ MONTHLY } \\
\hline \multicolumn{19}{|l|}{ YEARLY } \\
\hline SNOWMELTS & $*$ & $*$ & $*$ & * & $*$ & $*$ & $*$ & * & * & $*$ & $*$ & $*$ & $*$ & $*$ & $*$ & $*$ & $*$ & $*$ \\
\hline \multicolumn{19}{|l|}{ FLOWMONITORING (m3/s) } \\
\hline FLOW MONITORING INLET & $*$ & $*$ & $*$ & $*$ & * & * & $*$ & $*$ & $*$ & * & $*$ & * & $*$ & $*$ & $*$ & * & $*$ & $*$ \\
\hline FLOW MONITORING OUTLET & $*$ & $*$ & $*$ & $*$ & $*$ & $*$ & $*$ & $*$ & $*$ & $*$ & $*$ & $*$ & $*$ & $*$ & $*$ & $*$ & $*$ & $*$ \\
\hline PONDS LEVEL MONITORING (m) & $*$ & $*$ & $*$ & * & $*$ & * & $*$ & $*$ & * & * & $*$ & * & $*$ & $*$ & $*$ & $*$ & $*$ & $*$ \\
\hline WATER QUALITY MONITORING (Yes/No) & $*$ & $*$ & $*$ & $*$ & * & * & $*$ & $*$ & $*$ & * & $*$ & $*$ & $*$ & $*$ & $*$ & $*$ & $*$ & $*$ \\
\hline
\end{tabular}




\begin{tabular}{|c|c|c|c|c|c|c|c|c|c|c|c|c|c|c|c|c|c|c|}
\hline WATER QUALITY MONITORING INLET & YES & YES & YES & YES & YES & YES & YES & YES & YES & YES & YES & YES & YES & YES & YES & YES & YES & YES \\
\hline WATER QUALITY MONITORING OUTLET & YES & YES & YES & YES & YES & YES & YES & YES & YES & YES & YES & YES & YES & YES & YES & YES & YES & YES \\
\hline FLOW MONITORING STATION & 5 & 6 & 1 & 2 & 5 & 5 & 1 & 1 & 6 & 6 & 1 & 1 & 3 & 4 & 3 & 1 & 7 & 8 \\
\hline \multicolumn{19}{|l|}{ CATCHMENT } \\
\hline DRAINAGE AREA (ha) & 29 & 20.87 & 31.4 & 33.29 & 45.3 & 32 & 11.2 & 10 & 4.1 & 4 & 55.8 & 12.05 & 31 & 56 & 1.65 & 2.83 & 600 & 0 \\
\hline \multicolumn{19}{|l|}{ CATCHMENT AREA DELINEATION } \\
\hline DIGITALLY & * & * & $*$ & $*$ & $*$ & $*$ & $*$ & * & $*$ & $*$ & $*$ & * & $*$ & $*$ & $*$ & $*$ & $*$ & $*$ \\
\hline MANUALLY & $*$ & $*$ & $*$ & $*$ & $*$ & $*$ & $*$ & * & $*$ & $*$ & $*$ & $*$ & * & * & $*$ & $*$ & $*$ & $*$ \\
\hline \multicolumn{19}{|l|}{ ROAD NETWORK } \\
\hline DIGITALLY & $*$ & $*$ & $*$ & $*$ & $*$ & $*$ & $*$ & $*$ & $*$ & $*$ & $*$ & $*$ & $*$ & $*$ & $*$ & $*$ & $*$ & $*$ \\
\hline MANUALLY & * & * & * & * & $*$ & * & $*$ & $*$ & $*$ & $*$ & $*$ & $*$ & $*$ & $*$ & $*$ & $*$ & $*$ & $*$ \\
\hline \multicolumn{19}{|l|}{ STORM SEWER COLLECTION NETWORK } \\
\hline DIGITALLY & $*$ & $*$ & $*$ & $*$ & $*$ & $*$ & $*$ & $*$ & $*$ & $*$ & $*$ & $*$ & $*$ & $*$ & $*$ & $*$ & $*$ & $*$ \\
\hline MANUALLY & * & $*$ & $*$ & $*$ & $*$ & $*$ & $*$ & * & $*$ & $*$ & $*$ & $*$ & * & * & $*$ & $*$ & * & $*$ \\
\hline \multicolumn{19}{|l|}{ IMPERVIOUS SURFACES } \\
\hline IMPERVIOUS ROOFS & $*$ & $*$ & $*$ & $*$ & $*$ & $*$ & $*$ & $*$ & $*$ & $*$ & $*$ & $*$ & $*$ & $*$ & $*$ & $*$ & * & $*$ \\
\hline IMPERVIOUS SIDE WALKS & $*$ & $*$ & $*$ & $*$ & $*$ & $*$ & $*$ & $*$ & $*$ & $*$ & $*$ & $*$ & $*$ & $*$ & $*$ & $*$ & $*$ & $*$ \\
\hline IMPERVIOUS PARKING LOTS & $*$ & $*$ & $*$ & $*$ & $*$ & $*$ & $*$ & $*$ & $*$ & $*$ & $*$ & $*$ & $*$ & $*$ & $*$ & $*$ & $*$ & $*$ \\
\hline IMPERVIOUS DRIVEWAYS & $*$ & $*$ & $*$ & $*$ & $*$ & $*$ & $*$ & $*$ & $*$ & $*$ & $*$ & $*$ & $*$ & $*$ & $*$ & $*$ & $*$ & $*$ \\
\hline IMPERVIOUS AREA (m2) & $*$ & $*$ & $*$ & $*$ & $*$ & $*$ & $*$ & $*$ & $*$ & * & $*$ & $*$ & $*$ & $*$ & $*$ & * & $*$ & $*$ \\
\hline LANDUSE (TOTAL IMPERVIOUSNESS \%) & $*$ & $*$ & $*$ & $*$ & $*$ & $*$ & $*$ & $*$ & $*$ & $*$ & $*$ & $*$ & $*$ & * & $*$ & $*$ & $*$ & $*$ \\
\hline \multicolumn{19}{|l|}{ COMMERCIAL (695 HA) } \\
\hline \multicolumn{19}{|l|}{ INDUSTRIAL (1311HA) } \\
\hline \multicolumn{19}{|l|}{ INSTITUITIONAL (644HA) } \\
\hline \multicolumn{19}{|l|}{ RESIDENTIAL (4074HA) } \\
\hline \multicolumn{19}{|l|}{ AGRICULTURE (2047HA) } \\
\hline EMPLOYMENT (OHA) & & & & & & & & & & & & & & & & & & \\
\hline
\end{tabular}




\begin{tabular}{|c|c|c|c|c|c|c|c|c|c|c|c|c|c|c|c|c|c|c|}
\hline MIXED USE (OHA) & & & & & & & & & & & & & & & & & & \\
\hline \multicolumn{19}{|l|}{ OPEN SPACE (2002HA) } \\
\hline \multicolumn{19}{|l|}{ UTILITY (158HA) } \\
\hline \multicolumn{19}{|l|}{ RECREATIONAL (515HA) } \\
\hline CATCHMENT CHANGES & & * & & & * & & & & & & & $*$ & $*$ & & & $*$ & $*$ & \\
\hline LOW RISK & & & & & & & & 1 & & & & & & & & & & \\
\hline MEDUIM RISK & & & & & & & 2 & & & 2 & & & & & & & & \\
\hline HIGH RISK & 3 & & 3 & 3 & & 3 & & & 3 & & 3 & & & 3 & 3 & & & \\
\hline CATCHMENT PRACTICES & & & & & & & & & & & & & & & & & & 4 \\
\hline CATCH BASIN CLEANING & $*$ & $*$ & $*$ & $*$ & $*$ & $*$ & $*$ & $*$ & $*$ & $*$ & $*$ & $*$ & $*$ & $*$ & $*$ & $*$ & $*$ & $*$ \\
\hline STREET SWEEPING & * & * & $*$ & * & * & * & $*$ & * & $*$ & * & $*$ & * & $*$ & $*$ & $*$ & $*$ & $*$ & $*$ \\
\hline ROAD SALTING & $*$ & $*$ & $*$ & $*$ & $*$ & $*$ & $*$ & $*$ & $*$ & $*$ & $*$ & $*$ & $*$ & $*$ & $*$ & $*$ & $*$ & $*$ \\
\hline \multirow[t]{2}{*}{ ROAD SANDING PRACTICES } & $*$ & $*$ & $*$ & $*$ & $*$ & $*$ & $*$ & * & $*$ & * & $*$ & $*$ & $*$ & $*$ & $*$ & $*$ & $*$ & $*$ \\
\hline & $*$ & $*$ & $*$ & * & * & * & $*$ & * & $*$ & * & $*$ & $*$ & $*$ & $*$ & $*$ & $*$ & $*$ & $*$ \\
\hline \multicolumn{19}{|l|}{ STORM WATER PONDS } \\
\hline DESIGN OF PONDS & 1 & 1 & 1 & 1 & 1 & 1 & 1 & 1 & 1 & 1 & 1 & 1 & 1 & 1 & 1 & 1 & 1 & 1 \\
\hline \multicolumn{19}{|l|}{ AS-BUILT DRAWINGS } \\
\hline \multicolumn{19}{|l|}{ INLET STRUCTURE } \\
\hline DIGITALLY & $*$ & $*$ & $*$ & $*$ & $*$ & $*$ & $*$ & $*$ & $*$ & $*$ & $*$ & $*$ & $*$ & $*$ & $*$ & $*$ & $*$ & $*$ \\
\hline MANUALLY & $*$ & $*$ & $*$ & $*$ & * & * & $*$ & $*$ & $*$ & $*$ & $*$ & * & $*$ & $*$ & $*$ & * & * & * \\
\hline \multicolumn{19}{|l|}{ OUTLET STRUCTURE } \\
\hline DIGITALLY & $*$ & $*$ & $*$ & $*$ & $*$ & $*$ & $*$ & $*$ & $*$ & $*$ & $*$ & $*$ & $*$ & $*$ & $*$ & $*$ & $*$ & $*$ \\
\hline MANUALLY & * & * & $*$ & * & * & * & $*$ & * & $*$ & * & ${ }^{*}$ & * & * & $*$ & $*$ & $*$ & $*$ & $*$ \\
\hline \multicolumn{19}{|l|}{ PRESCENCE OF FOREBAY } \\
\hline YES & yes & yes & & yes & yes & yes & & & & & yes & yes & yes & & & yes & & \\
\hline NO & & & NO & & & & NO & NO & NO & NO & & & & NO & NO & & NO & NO \\
\hline IMPERVIOUS AREA (\%) & 55 & 8 & 28 & 47 & 4 & 54 & 5 & 48 & 55 & 53 & 4 & 43 & 5 & 51 & 39 & 35 & 7 & 77 \\
\hline PERMANENT POOL VOLUME (m3) & 3130 & 1440 & $*$ & 3407 & 1200 & 2500 & $*$ & $*$ & $*$ & * & * & * & 620 & 7457 & * & 25 & $*$ & * \\
\hline
\end{tabular}




\begin{tabular}{|c|c|c|c|c|c|c|c|c|c|c|c|c|c|c|c|c|c|c|}
\hline EXTENDED DETENTION REQUIREMENT (m3) & 1206 & 1220 & 4022 & 6805 & 16000 & 1329 & * & 1612 & 255 & 0 & 3848 & 1220 & 1240 & 6482 & 310 & 191 & $*$ & 0 \\
\hline TOTAL STORAGE VOLUME (m3) & 9840 & 4930 & 5265 & 2500 & 16000 & 16020 & 492 & 1536 & 581 & 11822 & 4000 & 1892 & 3874 & 14919 & 320 & 191 & 56375 & 6576 \\
\hline SEDIMENT LOAD REMOVED (m3/ha) & $*$ & * & * & $*$ & $*$ & $*$ & $*$ & 92 & * & $*$ & * & * & 105 & $*$ & $*$ & $*$ & $*$ & $*$ \\
\hline DESIGN TSS REMOVAL (\%) & $80 \%$ & $60 \%$ & 0 & 80 & 60 & 80 & 60 & 80 & 60 & 0 & 0 & 0 & 40 & 80 & 0 & 40 & 40 & 0 \\
\hline SEDIMENT VOLUME (m3) & $*$ & 190 & $*$ & $*$ & 1690 & $*$ & $*$ & 180 & $*$ & $*$ & 350 & $*$ & $*$ & 364 & 10 & * & $*$ & $*$ \\
\hline PERCENTAGE STORAGE LOSS (\%) & * & * & * & * & 41 & 8 & 27 & * & * & $*$ & 9 & * & * & * & $*$ & * & * & $*$ \\
\hline NUMBER OF CELLS & * & $*$ & $*$ & $*$ & $*$ & $*$ & * & * & * & $*$ & * & $*$ & * & * & * & * & * & * \\
\hline LENGTH/WIDTH RATIO & $*$ & * & $*$ & * & $*$ & $*$ & * & $*$ & * & $*$ & * & * & $*$ & * & * & * & $*$ & $*$ \\
\hline ACCUMALATED SEDIMENTS & $*$ & $*$ & $*$ & $*$ & $*$ & $*$ & $*$ & * & $*$ & $*$ & $*$ & $*$ & $*$ & * & $*$ & $*$ & $*$ & $*$ \\
\hline \multicolumn{19}{|l|}{ SURVEYED (YES/NO) } \\
\hline YES & 1 & 1 & 1 & 1 & 1 & 1 & 1 & 1 & 1 & 1 & 1 & 1 & 1 & & 1 & 1 & 1 & 1 \\
\hline NO & & & & & & & & & & & & & & 2 & & & & \\
\hline SURVEY DATES & 2008 & 2008 & 2008 & 2008 & 2008 & 2008 & 2008 & 2008 & 2008 & 2008 & 2008 & 2008 & 2008 & & 2008 & 2008 & 2008 & 2008 \\
\hline \multicolumn{19}{|l|}{ SURVEY RESULTS } \\
\hline RETROFIT & & $*$ & & & $*$ & & $*$ & $*$ & * & $*$ & $*$ & * & * & * & $*$ & * & & \\
\hline PLANNED & & & 1 & & & & & & & & & & & & & & 1 & 1 \\
\hline PREVIOUSLY & 2 & & & 2 & & 2 & & & & & & & & & & & & \\
\hline \multicolumn{19}{|l|}{ NOT FEASIBLE } \\
\hline YEAR RETROFIT COMPLETE & 2010 & & & 2010 & & 2013 & & & & & & & 2009 & & & & & \\
\hline \multicolumn{19}{|l|}{ SEDIMENT CHARACTERIZATION } \\
\hline DIGITALLY & $*$ & $*$ & $*$ & $*$ & $*$ & $*$ & $*$ & * & $*$ & $*$ & $*$ & $*$ & $*$ & $*$ & $*$ & $*$ & $*$ & $*$ \\
\hline MANUALLY & $*$ & $*$ & $*$ & $*$ & $*$ & $*$ & $*$ & $*$ & $*$ & $*$ & $*$ & $*$ & $*$ & $*$ & $*$ & $*$ & $*$ & $*$ \\
\hline \multicolumn{19}{|l|}{ PLANTING RECORDS(YES/NO) } \\
\hline YES & * & * & * & * & $*$ & * & * & * & * & $*$ & * & * & * & * & * & * & * & * \\
\hline NO & $*$ & $*$ & $*$ & * & $*$ & $*$ & $*$ & $*$ & * & $*$ & $*$ & $*$ & $*$ & * & $*$ & * & $*$ & $*$ \\
\hline \multicolumn{19}{|l|}{ PONDS USE FOR IRRIGATION (YES/NO) } \\
\hline YES & $*$ & * & $*$ & * & $*$ & $*$ & $*$ & * & $*$ & $*$ & $*$ & $*$ & $*$ & $*$ & $*$ & * & $*$ & $*$ \\
\hline NO & $*$ & $*$ & $*$ & $*$ & $*$ & $*$ & * & * & $*$ & * & $*$ & * & * & $*$ & $*$ & $*$ & * & $*$ \\
\hline
\end{tabular}


Municipality A (2006-2013)

\begin{tabular}{|c|c|c|c|c|c|c|c|c|c|c|c|c|c|c|c|c|c|c|c|}
\hline SWM FACILITY\# & 74 & 84 & 85 & 94 & 95 & 96 & 97 & 101 & 105 & 107 & 115 & 118 & 120 & 125 & 131 & 143 & 146 & 147 & 156 \\
\hline YEAR OF CONSTRUCTION & 2006 & 2005 & 2007 & 2002 & 1999 & 1999 & 1999 & 2003 & 1989 & 2005 & 2008 & 2005 & 1999 & 2006 & 2005 & 2004 & 2006 & 2002 & 2013 \\
\hline \multicolumn{20}{|l|}{ TYPE OF FACILITY } \\
\hline \multicolumn{20}{|l|}{ DRY POND } \\
\hline WET POND & 2 & 2 & 2 & 2 & 2 & 2 & 2 & 2 & 2 & 2 & 2 & 2 & 2 & 2 & 2 & 2 & 2 & & 2 \\
\hline \multicolumn{20}{|l|}{ WETLAND } \\
\hline WETLAND/WETPOND & & & & & & & & & & & & & & & & & & 4 & \\
\hline \multicolumn{20}{|l|}{ MAINTAINENCE PRIORITY } \\
\hline HIGH PRIORITY & & & & 1 & 1 & & & 1 & & & & & 1 & & & & 1 & & \\
\hline \multicolumn{20}{|l|}{ MODERATE PRIORITY } \\
\hline \multicolumn{20}{|l|}{ LOW PRIORITY } \\
\hline \multicolumn{20}{|l|}{ HYDROLOGIC DATA } \\
\hline \multicolumn{20}{|l|}{ CLOSEST ENVIORMENT RAINGUAGE } \\
\hline FROM MUNICIPALITY & RG1 & RG3 & RG3 & RG1 & RG1 & RG1 & RG1 & RG2 & RG3 & RG2 & RG1 & RG3 & RG1 & RG3 & RG4 & RG3 & $\mathrm{RG} 2$ & RG2 & RG1 \\
\hline FROM ENVIORMENT CANADA & S07 & S07 & S07 & S07 & S07 & S07 & S07 & S07 & S07 & S07 & S07 & S07 & S07 & S07 & S07 & S07 & S07 & S07 & S07 \\
\hline \multicolumn{20}{|l|}{ PRECIPITATION RECORDS(mm) } \\
\hline HOURLY & 32.4 & 30.8 & 30.8 & 32.4 & 32.4 & 32.4 & 32.4 & 18.6 & 30.8 & 18.6 & 32.4 & 30.8 & 32.4 & 30.8 & 31.6 & 30.8 & 18.6 & 18.6 & 32.4 \\
\hline \multicolumn{20}{|l|}{ DAILY } \\
\hline \multicolumn{20}{|l|}{ MONTHLY } \\
\hline \multicolumn{20}{|l|}{ YEARLY } \\
\hline SNOWMELTS & * & $*$ & $*$ & $*$ & $*$ & * & $*$ & $*$ & $*$ & $*$ & * & * & $*$ & $*$ & $*$ & $*$ & $*$ & $*$ & $*$ \\
\hline FLOWMONITORING (m3/s) & * & $*$ & $*$ & * & $*$ & $*$ & $*$ & * & $*$ & * & * & $*$ & $*$ & $*$ & $*$ & $*$ & $*$ & $*$ & $*$ \\
\hline FLOW MONITORING INLET & * & * & * & * & * & * & $*$ & * & * & * & * & * & * & * & * & * & * & * & * \\
\hline FLOW MONITORING OUTLET & * & * & * & * & * & * & * & * & * & * & * & * & * & * & * & * & * & * & * \\
\hline PONDS LEVEL MONITORING (m) & * & * & * & * & * & * & * & * & * & * & * & * & * & * & * & * & $*$ & * & ${ }^{*}$ \\
\hline WATER QUALITY MONITORING (Yes/No) & * & * & * & * & * & * & * & * & * & * & * & * & * & * & * & * & * & * & * \\
\hline
\end{tabular}




\begin{tabular}{|c|c|c|c|c|c|c|c|c|c|c|c|c|c|c|c|c|c|c|c|}
\hline WATER QUALITY MONITORING INLET & YES & YES & YES & YES & YES & YES & YES & YES & YES & YES & YES & YES & YES & YES & YES & YES & YES & YES & YES \\
\hline WATER QUALITY MONITORING OUTLET & YES & YES & YES & YES & YES & YES & YES & YES & YES & YES & YES & YES & YES & YES & YES & YES & YES & YES & YES \\
\hline FLOW MONITORING STATION & 1 & 2 & 1 & 4 & 2 & 4 & 1 & 2 & 9 & 10 & 1 & 5 & 7 & 9 & 1 & 8 & 2 & 4 & 2 \\
\hline \multicolumn{20}{|l|}{ CATCHMENT } \\
\hline DRAINAGE AREA (HA) & 25.6 & 13.2 & 40 & 25.49 & 17.8 & 32.9 & 60 & 22 & 7.64 & 70.1 & 32.46 & 36.28 & 4.2 & 20.6 & 20.35 & 17.4 & 21.4 & 3.2 & 18.6 \\
\hline \multicolumn{20}{|l|}{ CATCHMENT AREA DELINEATION } \\
\hline DIGITALLY & $*$ & $*$ & $*$ & $*$ & * & $*$ & $*$ & $*$ & $*$ & $*$ & * & $*$ & $*$ & $*$ & * & $*$ & $*$ & $*$ & $*$ \\
\hline MANUALLY & $*$ & $*$ & $*$ & $*$ & $*$ & $*$ & * & $*$ & $*$ & $*$ & * & $*$ & $*$ & $*$ & $*$ & * & $*$ & $*$ & $*$ \\
\hline \multicolumn{20}{|l|}{ ROAD NETWORK } \\
\hline DIGITALLY & $*$ & $*$ & $*$ & $*$ & $*$ & $*$ & * & $*$ & $*$ & $*$ & $*$ & $*$ & $*$ & $*$ & $*$ & $*$ & $*$ & $*$ & $*$ \\
\hline MANUALLY & $*$ & $*$ & $*$ & $*$ & $*$ & $*$ & * & * & $*$ & $*$ & $*$ & $*$ & $*$ & $*$ & $*$ & $*$ & $*$ & $*$ & $*$ \\
\hline \multicolumn{20}{|l|}{ STORM SEWER COLLECTION NETWORK } \\
\hline DIGITALLY & $*$ & $*$ & $*$ & $*$ & $*$ & $*$ & $*$ & $*$ & $*$ & * & $*$ & $*$ & $*$ & $*$ & $*$ & $*$ & $*$ & $*$ & $*$ \\
\hline MANUALLY & $*$ & $*$ & $*$ & $*$ & $*$ & $*$ & * & * & $*$ & $*$ & $*$ & $*$ & $*$ & $*$ & * & * & $*$ & $*$ & $*$ \\
\hline \multicolumn{20}{|l|}{ IMPERVIOUS SURFACES } \\
\hline IMPERVIOUS ROOFS & $*$ & $*$ & $*$ & $*$ & $*$ & $*$ & $*$ & $*$ & $*$ & $*$ & $*$ & $*$ & $*$ & $*$ & $*$ & $*$ & $*$ & $*$ & $*$ \\
\hline IMPERVIOUS SIDE WALKS & $*$ & $*$ & $*$ & $*$ & $*$ & $*$ & $*$ & $*$ & $*$ & $*$ & $*$ & $*$ & $*$ & $*$ & $*$ & $*$ & $*$ & $*$ & $*$ \\
\hline IMPERVIOUS PARKING LOTS & $*$ & $*$ & $*$ & $*$ & $*$ & $*$ & $*$ & $*$ & $*$ & $*$ & $*$ & $*$ & $*$ & $*$ & $*$ & $*$ & $*$ & $*$ & $*$ \\
\hline IMPERVIOUS DRIVEWAYS & $*$ & $*$ & $*$ & $*$ & $*$ & $*$ & $*$ & $*$ & $*$ & $*$ & $*$ & $*$ & $*$ & $*$ & $*$ & $*$ & $*$ & $*$ & $*$ \\
\hline IMPERVIOUS AREA (m2) & $*$ & $*$ & $*$ & $*$ & $*$ & $*$ & * & $*$ & $*$ & $*$ & $*$ & $*$ & $*$ & $*$ & $*$ & $*$ & $*$ & $*$ & $*$ \\
\hline LANDUSE (TOTAL IMPERVIOUSNESS \%) & $*$ & $*$ & $*$ & $*$ & $*$ & $*$ & $*$ & $*$ & $*$ & $*$ & $*$ & $*$ & $*$ & $*$ & * & $*$ & $*$ & $*$ & $*$ \\
\hline \multicolumn{20}{|l|}{ COMMERCIAL (695 HA) } \\
\hline \multicolumn{20}{|l|}{ INDUSTRIAL (1311HA) } \\
\hline \multicolumn{20}{|l|}{ INSTITUITIONAL (644HA) } \\
\hline \multicolumn{20}{|l|}{ RESIDENTIAL (4074HA) } \\
\hline \multicolumn{20}{|l|}{ AGRICULTURE (2047HA) } \\
\hline EMPLOYMENT (OHA) & & & & & & & & & & & & & & & & & & & \\
\hline
\end{tabular}




\begin{tabular}{|c|c|c|c|c|c|c|c|c|c|c|c|c|c|c|c|c|c|c|c|}
\hline MIXED USE (OHA) & & & & & & & & & & & & & & & & & & & \\
\hline \multicolumn{20}{|l|}{ OPEN SPACE (2002HA) } \\
\hline \multicolumn{20}{|l|}{ UTILITY (158HA) } \\
\hline \multicolumn{20}{|l|}{ RECREATIONAL (515HA) } \\
\hline CATCHMENT CHANGES & & & $*$ & & & & & $*$ & $*$ & $*$ & & & & $*$ & $*$ & $*$ & $*$ & $*$ & $*$ \\
\hline LOW RISK & & & & & & & & & & & & & 1 & & & & & & \\
\hline MEDUIM RISK & 2 & & & & & & & & & & & & & & & & & & \\
\hline HIGH RISK & & & & 3 & 3 & 3 & 3 & & & & 3 & 3 & & & & & & & \\
\hline CATCHMENT PRACTICES & & 4 & & & & & & & & & & & & & & & & & \\
\hline CATCH BASIN CLEANING & $*$ & $*$ & $*$ & $*$ & $*$ & $*$ & $*$ & $*$ & $*$ & $*$ & $*$ & $*$ & $*$ & $*$ & * & $*$ & $*$ & $*$ & $*$ \\
\hline STREET SWEEPING & * & $*$ & $*$ & $*$ & $*$ & $*$ & $*$ & $*$ & $*$ & $*$ & * & * & $*$ & $*$ & * & * & $*$ & $*$ & $*$ \\
\hline ROAD SALTING & $*$ & $*$ & $*$ & $*$ & $*$ & $*$ & $*$ & $*$ & $*$ & $*$ & $*$ & * & $*$ & $*$ & * & $*$ & $*$ & $*$ & $*$ \\
\hline \multirow[t]{2}{*}{ ROAD SANDING PRACTICES } & $*$ & $*$ & $*$ & $*$ & $*$ & $*$ & $*$ & $*$ & $*$ & $*$ & $*$ & $*$ & $*$ & $*$ & $*$ & $*$ & $*$ & $*$ & $*$ \\
\hline & * & * & $*$ & $*$ & $*$ & $*$ & * & $*$ & $*$ & * & * & $*$ & $*$ & $*$ & * & * & $*$ & $*$ & $*$ \\
\hline STORM WATER PONDS & & & & & & & & & & & & & & & & 2 & & 2 & \\
\hline DESIGN OF PONDS & & & & & & & & & & & & 3 & & & & & & & \\
\hline \multicolumn{20}{|l|}{ AS-BUILT DRAWINGS } \\
\hline \multicolumn{20}{|l|}{ INLET STRUCTURE } \\
\hline DIGITALLY & $*$ & $*$ & $*$ & $*$ & $*$ & $*$ & $*$ & $*$ & $*$ & $*$ & $*$ & $*$ & $*$ & $*$ & $*$ & $*$ & $*$ & $*$ & $*$ \\
\hline MANUALLY & $*$ & $*$ & $*$ & $*$ & $*$ & $*$ & $*$ & $*$ & $*$ & $*$ & $*$ & $*$ & $*$ & $*$ & * & $*$ & $*$ & $*$ & $*$ \\
\hline \multicolumn{20}{|l|}{ OUTLET STRUCTURE } \\
\hline DIGITALLY & $*$ & $*$ & $*$ & $*$ & $*$ & $*$ & $*$ & $*$ & $*$ & $*$ & $*$ & $*$ & $*$ & $*$ & $*$ & $*$ & $*$ & $*$ & $*$ \\
\hline MANUALLY & $*$ & $*$ & $*$ & $*$ & $*$ & $*$ & $*$ & $*$ & $*$ & $*$ & $*$ & $*$ & $*$ & $*$ & $*$ & $*$ & $*$ & $*$ & $*$ \\
\hline \multicolumn{20}{|l|}{ PRESCENCE OF FOREBAY } \\
\hline YES & yes & yes & yes & yes & yes & yes & yes & yes & & yes & yes & yea & no & yes & yes & yes & yes & yes & \\
\hline NO & & & & & & & & & NO & & & & & & & & & & NO \\
\hline IMPERVIOUS AREA (\%) & 55 & 6 & 6 & 37 & 59 & 56 & 52 & 55 & 6 & 48 & 5 & 55 & 5 & 55 & 25 & 85 & 55 & 75 & 2 \\
\hline PERMANENT POOL VOLUME (m3) & 1400 & 1236 & 3161 & 2220 & 390 & 935 & 2096 & $*$ & $*$ & 3864 & 5343 & 3513 & 147 & 262 & 546 & 2029 & 647 & 64 & $*$ \\
\hline
\end{tabular}




\begin{tabular}{|c|c|c|c|c|c|c|c|c|c|c|c|c|c|c|c|c|c|c|c|}
\hline EXTENDED DETENTION REQUIREMENT (m3) & 5904 & 528 & 1600 & 10858 & 715 & 1316 & 2067 & 3237 & 0 & 8625 & 1298 & 3714 & 168 & 927 & 742 & 695 & 5277 & 128 & $*$ \\
\hline TOTAL STORAGE VOLUME (m3) & 11980 & 6140 & 10560 & 13072 & 1070 & 1934 & 1974 & 4125 & $*$ & 16849 & 10601 & 8831 & 1000 & 2872 & 1366 & 2223 & 7916 & 1302 & * \\
\hline SEDIMENT LOAD REMOVED (m3/ha) & * & * & * & * & * & * & 4 & * & $*$ & * & * & * & * & * & $*$ & 7 & $*$ & $*$ & * \\
\hline DESIGN TSS REMOVAL (\%) & 60 & 60 & 80 & 80 & 40 & 40 & 80 & 0 & 0 & 80 & 80 & 80 & 40 & 40 & 40 & 80 & 40 & 40 & 0 \\
\hline SEDIMENT VOLUME (m3) & 130 & 290 & 703 & 950 & 950 & 540 & * & 1170 & $*$ & * & 369 & 132 & 105 & 598 & 0 & * & 433 & 144 & 1690 \\
\hline PERCENTAGE STORAGE LOSS (\%) & $*$ & * & * & 7 & 35 & 28 & $*$ & 28 & $*$ & * & * & $*$ & 42 & * & 17 & $*$ & 11 & 48 & $* *$ \\
\hline NUMBER OF CELLS & * & * & $*$ & * & * & * & * & * & $*$ & * & * & $*$ & $*$ & * & $*$ & * & $*$ & $*$ & $*$ \\
\hline LENGTH/WIDTH RATIO & * & * & $*$ & * & * & $*$ & * & * & $*$ & * & * & * & $*$ & * & * & * & $*$ & $*$ & * \\
\hline ACCUMALATED SEDIMENTS & * & $*$ & $*$ & $*$ & $*$ & $*$ & $*$ & $*$ & $*$ & $*$ & * & $*$ & * & $*$ & $*$ & $*$ & $*$ & $*$ & $*$ \\
\hline \multicolumn{20}{|l|}{ SURVEYED (YES/NO) } \\
\hline YES & & & & 1 & 1 & 1 & 1 & 1 & 1 & 1 & & & & & & & & & \\
\hline NO & 2 & 2 & 2 & & & & & & & & 2 & 2 & 2 & 2 & 2 & 2 & 2 & 2 & 2 \\
\hline SURVEY DATES & & & & 2008 & 2008 & 2008 & 2008 & 2008 & 2008 & 2008 & & & & & & & & & \\
\hline \multicolumn{20}{|l|}{ SURVEY RESULTS } \\
\hline RETROFIT & $*$ & $*$ & $*$ & $*$ & $*$ & $*$ & $*$ & $*$ & $*$ & & $*$ & $*$ & $*$ & $*$ & $*$ & $*$ & $*$ & $*$ & $*$ \\
\hline \multicolumn{20}{|l|}{ PLANNED } \\
\hline PREVIOUSLY & & & & & & & & & & 2 & & & & & & & & & \\
\hline \multicolumn{20}{|l|}{ NOT FEASIBLE } \\
\hline YEAR RETROFIT COMPLETE & & & & 2015 & & & & & & 2015 & & & & 2015 & & & & & \\
\hline \multicolumn{20}{|l|}{ SEDIMENT CHARACTERIZATION } \\
\hline DIGITALLY & $*$ & $*$ & $*$ & $*$ & $*$ & $*$ & * & $*$ & $*$ & $*$ & * & $*$ & $*$ & $*$ & $*$ & $*$ & $*$ & $*$ & $*$ \\
\hline MANUALLY & $*$ & * & $*$ & * & * & * & * & * & $*$ & * & * & * & * & * & * & * & $*$ & $*$ & * \\
\hline \multicolumn{20}{|l|}{ PLANTING RECORDS(YES/NO) } \\
\hline YES & $*$ & * & $*$ & * & $*$ & $*$ & $*$ & * & $*$ & * & * & * & * & * & * & * & $*$ & $*$ & * \\
\hline NO & $*$ & $*$ & $*$ & $*$ & $*$ & $*$ & $*$ & $*$ & $*$ & $*$ & $*$ & $*$ & * & * & * & * & * & $*$ & * \\
\hline \multicolumn{20}{|l|}{ PONDS USE FOR IRRIGATION (YES/NO) } \\
\hline YES & * & * & $*$ & $*$ & $*$ & $*$ & $*$ & * & $*$ & $*$ & $*$ & $*$ & $*$ & $*$ & $*$ & $*$ & $*$ & $*$ & $*$ \\
\hline NO & * & $*$ & $*$ & $*$ & * & $*$ & * & * & * & * & * & * & * & * & * & * & $*$ & $*$ & * \\
\hline
\end{tabular}




\section{Municipality B}

\begin{tabular}{|c|c|c|c|c|c|c|c|c|c|c|c|c|c|}
\hline SWM FACILITY\# & $1 \mathrm{~A}$ & $1 \mathrm{~B}$ & 2 & 3 & 4 & 5 & 6 & 7 & 8 & 9 & 10 & 11 & 14 \\
\hline YEAR OF CONSTRUCTION & 1999 & 1999 & 1991 & 1990 & 2000 & 1993 & 2012 & 2008 & 2008 & 2010 & 2009 & 2012 & 1994 \\
\hline \multicolumn{14}{|l|}{ TYPE OF FACILITY } \\
\hline \multicolumn{14}{|l|}{ DRY POND } \\
\hline WET POND & 2 & 2 & 2 & 2 & 2 & 2 & 2 & 2 & 2 & 2 & 2 & 2 & 2 \\
\hline \multicolumn{14}{|l|}{ WETLAND } \\
\hline \multicolumn{14}{|l|}{ WETLAND/WETPOND } \\
\hline \multicolumn{14}{|l|}{ MAINTAINENCE PRIORITY } \\
\hline HIGH PRIORITY & 1 & 1 & 1 & & 1 & & & 1 & & 1 & 1 & 1 & 1 \\
\hline MODERATE PRIORITY & & & & 2 & & 2 & 2 & & 2 & & & & \\
\hline \multicolumn{14}{|l|}{ LOW PRIORITY } \\
\hline \multicolumn{14}{|l|}{ HYDROLOGIC DATA } \\
\hline \multicolumn{14}{|l|}{$\begin{array}{c}\text { CLOSEST ENVIORMENT } \\
\text { RAINGUAGE }\end{array}$} \\
\hline \multicolumn{14}{|l|}{ FROM MUNICIPALITY } \\
\hline FROM ENVIORMENT CANADA & 15004 & 15004 & 15004 & 15004 & 15004 & 15004 & 15004 & 15004 & 15004 & 15004 & 15004 & 15004 & 15004 \\
\hline \multicolumn{14}{|l|}{ PRECIPITATION RECORDS(mm) } \\
\hline HOURLY & 30.1 & 30.1 & 30.1 & 30.1 & 30.1 & 30.1 & 30.1 & 30.1 & 30.1 & 30.1 & 30.1 & 30.1 & 30.1 \\
\hline \multicolumn{14}{|l|}{ DAILY } \\
\hline \multicolumn{14}{|l|}{ MONTHLY } \\
\hline \multicolumn{14}{|l|}{ YEARLY } \\
\hline SNOWMELTS & $*$ & $*$ & * & $*$ & $*$ & * & * & * & $*$ & $*$ & $*$ & $*$ & $*$ \\
\hline \multicolumn{14}{|l|}{ FLOWMONITORING (m3/s) } \\
\hline \multicolumn{14}{|l|}{ FLOW MONITORING INLET } \\
\hline FLOW MONITORING OUTLET & 0.22 & 0.38 & 0.16 & 0.06 & 0.44 & 0.36 & 0.28 & 0.12 & 0.35 & 0.18 & 0.04 & 0.033 & 0.22 \\
\hline PONDS LEVEL MONITORING (m) & 221.11 & 111 & 224.03 & 149.4 & 222.32 & 224.1 & 120.22 & 133.4 & 192 & 224.1 & 128 & 116.12 & 122.11 \\
\hline $\begin{array}{l}\text { WATER QUALITY MONITORING } \\
\text { (Yes/No) }\end{array}$ & & & & & & & & & & & & & \\
\hline
\end{tabular}




\begin{tabular}{|c|c|c|c|c|c|c|c|c|c|c|c|c|c|}
\hline $\begin{array}{l}\text { WATER QUALITY MONITORING } \\
\text { INLET }\end{array}$ & YES & YES & YES & YES & YES & YES & YES & YES & YES & YES & YES & YES & YES \\
\hline $\begin{array}{c}\text { WATER QUALITY MONITORING } \\
\text { OUTLET } \\
\end{array}$ & YES & YES & YES & YES & YES & YES & YES & YES & YES & YES & YES & YES & YES \\
\hline \multicolumn{14}{|l|}{ FLOW MONITORING STATION } \\
\hline \multicolumn{14}{|l|}{ CATCHMENT } \\
\hline DRAINAGE AREA (HA) & 30.77 & 11.47 & 28.65 & 35.94 & 18.46 & $*$ & 25.18 & 35.48 & 14.72 & 41.08 & 35.34 & 31.84 & 6.31 \\
\hline \multicolumn{14}{|l|}{$\begin{array}{c}\text { CATCHMENT AREA } \\
\text { DELINEATION } \\
\end{array}$} \\
\hline \multicolumn{14}{|l|}{ DIGITALLY } \\
\hline \multicolumn{14}{|l|}{ MANUALLY } \\
\hline \multicolumn{14}{|l|}{ ROAD NETWORK } \\
\hline \multicolumn{14}{|l|}{ DIGITALLY } \\
\hline \multicolumn{14}{|l|}{ MANUALLY } \\
\hline \multicolumn{14}{|l|}{$\begin{array}{c}\text { STORM SEWER COLLECTION } \\
\text { NETWORK }\end{array}$} \\
\hline DIGITALLY & 1 & 1 & 1 & 1 & 1 & 1 & 1 & 1 & 1 & 1 & 1 & 1 & 1 \\
\hline \multicolumn{14}{|l|}{ MANUALLY } \\
\hline \multicolumn{14}{|l|}{ IMPERVIOUS SURFACES } \\
\hline IMPERVIOUS ROOFS & * & $*$ & * & * & * & $*$ & * & * & $*$ & * & * & * & * \\
\hline IMPERVIOUS SIDE WALKS & $*$ & $*$ & $*$ & $*$ & $*$ & $*$ & $*$ & $*$ & $*$ & $*$ & $*$ & $*$ & * \\
\hline IMPERVIOUS PARKING LOTS & $*$ & $*$ & $*$ & $*$ & $*$ & $*$ & $*$ & $*$ & * & $*$ & $*$ & $*$ & $*$ \\
\hline IMPERVIOUS DRIVEWAYS & $*$ & $*$ & $*$ & $*$ & $*$ & $*$ & $*$ & $*$ & $*$ & $*$ & $*$ & $*$ & $*$ \\
\hline IMPERVIOUS AREA (m2) & $*$ & * & $*$ & $*$ & $*$ & $*$ & $*$ & $*$ & $*$ & $*$ & $*$ & $*$ & * \\
\hline \multicolumn{14}{|l|}{$\begin{array}{c}\text { LANDUSE (TOTAL } \\
\text { IMPERVIOUSNESS \%) }\end{array}$} \\
\hline \multicolumn{14}{|l|}{ COMMERCIAL (695 HA) } \\
\hline \multicolumn{14}{|l|}{ INDUSTRIAL (1311HA) } \\
\hline \multicolumn{14}{|l|}{ INSTITUITIONAL (644HA) } \\
\hline \multicolumn{14}{|l|}{ RESIDENTIAL (4074HA) } \\
\hline \multicolumn{14}{|l|}{ AGRICULTURE (2047HA) } \\
\hline EMPLOYMENT (OHA) & & & & & & & & & & & & & \\
\hline
\end{tabular}




\begin{tabular}{|c|c|c|c|c|c|c|c|c|c|c|c|c|c|}
\hline MIXED USE (OHA) & & & & & & & & & & & & & \\
\hline \multicolumn{14}{|l|}{ OPEN SPACE (2002HA) } \\
\hline \multicolumn{14}{|l|}{ UTILITY (158HA) } \\
\hline \multicolumn{14}{|l|}{ RECREATIONAL (515HA) } \\
\hline \multicolumn{14}{|l|}{ CATCHMENT CHANGES } \\
\hline \multicolumn{14}{|l|}{ LOW RISK } \\
\hline \multicolumn{14}{|l|}{ MEDUIM RISK } \\
\hline \multicolumn{14}{|l|}{ HIGH RISK } \\
\hline \multicolumn{14}{|l|}{ CATCHMENT PRACTICES } \\
\hline CATCH BASIN CLEANING & * & * & * & * & $*$ & * & * & * & * & * & $*$ & $*$ & * \\
\hline STREET SWEEPING & * & * & * & * & * & * & * & * & * & $*$ & $*$ & $*$ & * \\
\hline ROAD SALTING & $*$ & $*$ & $*$ & $*$ & $*$ & $*$ & $*$ & $*$ & $*$ & $*$ & $*$ & $*$ & $*$ \\
\hline \multirow{2}{*}{ ROAD SANDING PRACTICES } & $*$ & $*$ & $*$ & $*$ & $*$ & $*$ & $*$ & $*$ & $*$ & $*$ & $*$ & $*$ & $*$ \\
\hline & * & $*$ & $*$ & $*$ & $*$ & $*$ & $*$ & $*$ & * & $*$ & $*$ & $*$ & * \\
\hline \multicolumn{14}{|l|}{ STORM WATER PONDS } \\
\hline \multicolumn{14}{|l|}{ DESIGN OF PONDS } \\
\hline AS-BUILT DRAWINGS & AVAILABLE & AVAILABLE & AVAILABLE & AVAILABLE & AVAILABLE & AVAILABLE & AVAILABLE & AVAILABLE & AVAILABLE & AVAILABLE & AVAILABLE & AVAILABLE & AVAILABLE \\
\hline \multicolumn{14}{|l|}{ INLET STRUCTURE } \\
\hline \multicolumn{14}{|l|}{ DIGITALLY } \\
\hline \multicolumn{14}{|l|}{ MANUALLY } \\
\hline \multicolumn{14}{|l|}{ OUTLET STRUCTURE } \\
\hline \multicolumn{14}{|l|}{ DIGITALLY } \\
\hline \multicolumn{14}{|l|}{ MANUALLY } \\
\hline \multicolumn{14}{|l|}{ PRESCENCE OF FOREBAY } \\
\hline \multicolumn{14}{|l|}{ YES } \\
\hline \multicolumn{14}{|l|}{ NO } \\
\hline IMPERVIOUS AREA (\%) & 3 & 4 & 4 & 5 & 6 & 9 & 4 & 65 & 4 & 3 & 3 & 4 & 55 \\
\hline $\begin{array}{l}\text { PERMANENT POOL VOLUME } \\
(\mathrm{m} 3)\end{array}$ & 6362 & 3878 & 4493 & 5500 & 900 & 1024 & $*$ & 3047 & 1160 & 1800 & 1220 & 1060 & 1356 \\
\hline
\end{tabular}




\begin{tabular}{|c|c|c|c|c|c|c|c|c|c|c|c|c|c|}
\hline $\begin{array}{c}\text { EXTENDED DETENTION } \\
\text { REQUIREMENT }(\mathrm{m} 3) \\
\end{array}$ & 125 & 125 & 666 & 125 & 780 & 990 & * & 840 & 119 & 920 & 832 & 635 & 320 \\
\hline TOTAL STORAGE VOLUME (m3) & 3750 & 3750 & $*$ & 4493 & $*$ & 3836 & $*$ & $*$ & $*$ & $*$ & $*$ & $*$ & $*$ \\
\hline $\begin{array}{l}\text { SEDIMENT LOAD REMOVED } \\
(\mathrm{m} 3 / \mathrm{ha})\end{array}$ & 258 & 135 & 352 & 248 & 323 & 15 & 282 & 38 & 23 & 47 & & 168 & \\
\hline DESIGN TSS REMOVAL (\%) & 40 & 0 & 60 & 60 & 80 & 40 & 40 & 0 & 0 & 80 & 0 & 60 & 40 \\
\hline SEDIMENT VOLUME (m3) & 295 & 274 & 624 & 544 & 248 & 323 & 15 & 288 & 38 & 395 & & 168 & \\
\hline PERCENTAGE STORAGE LOSS (\%) & 4.6 & 7.1 & 13.9 & 9.9 & 27.6 & 31.5 & $*$ & 9.5 & 3.3 & 21.9 & & 15.8 & \\
\hline \multicolumn{14}{|l|}{ NUMBER OF CELLS } \\
\hline LENGTH/WIDTH RATIO & $*$ & $*$ & $*$ & $*$ & $*$ & $*$ & $*$ & $*$ & $*$ & $*$ & $*$ & $*$ & $*$ \\
\hline \multicolumn{14}{|l|}{ ACCUMALATED SEDIMENTS } \\
\hline \multicolumn{14}{|l|}{ SURVEYED (YES/NO) } \\
\hline \multicolumn{14}{|l|}{ YES } \\
\hline \multicolumn{14}{|l|}{ NO } \\
\hline SURVEY DATES & 2009 & 2009 & 2009 & 2009 & 2009 & 2009 & 2009 & 2009 & 2009 & 2009 & 2009 & 2009 & 2009 \\
\hline \multicolumn{14}{|l|}{ SURVEY RESULTS } \\
\hline \multicolumn{14}{|l|}{ RETROFIT } \\
\hline \multicolumn{14}{|l|}{ PLANNED } \\
\hline \multicolumn{14}{|l|}{ PREVIOUSLY } \\
\hline \multicolumn{14}{|l|}{ NOT FEASIBLE } \\
\hline \multicolumn{14}{|l|}{ YEAR RETROFIT COMPLETE } \\
\hline \multicolumn{14}{|l|}{ SEDIMENT CHARACTERIZATION } \\
\hline DIGITALLY & $*$ & $*$ & $*$ & $*$ & $*$ & $*$ & $*$ & $*$ & $*$ & $*$ & $*$ & $*$ & $*$ \\
\hline MANUALLY & $*$ & $*$ & $*$ & $*$ & $*$ & $*$ & $*$ & $*$ & $*$ & $*$ & $*$ & $*$ & * \\
\hline \multicolumn{14}{|l|}{ PLANTING RECORDS(YES/NO) } \\
\hline YES & $*$ & $*$ & $*$ & $*$ & $*$ & $*$ & $*$ & $*$ & * & $*$ & $*$ & $*$ & * \\
\hline NO & * & * & * & * & * & * & * & * & * & * & * & * & * \\
\hline \multicolumn{14}{|l|}{$\begin{array}{c}\text { PONDS USE FOR IRRIGATION } \\
\text { (YES/NO) }\end{array}$} \\
\hline YES & * & * & $*$ & * & * & $*$ & * & * & * & * & * & $*$ & $*$ \\
\hline NO & * & * & * & * & * & * & * & * & * & * & * & * & * \\
\hline
\end{tabular}


Municipality C

\begin{tabular}{|c|c|c|c|c|c|c|c|c|c|c|c|c|}
\hline SWM FACILITY\# & 6 & 48 & 55 & 56 & 57 & 58 & 71 & 73 & 74 & 75 & 76 & 77 \\
\hline YEAR OF CONSTRUCTION & 1999 & 1994 & 1999 & 1997 & 1997 & 2012 & 2010 & 2008 & 2008 & 2009 & 2007 & 2010 \\
\hline \multicolumn{13}{|l|}{ TYPE OF FACILITY } \\
\hline \multicolumn{13}{|l|}{ DRY POND } \\
\hline WET POND & 2 & 2 & 2 & 2 & 2 & 2 & 2 & 2 & 2 & 2 & 2 & 2 \\
\hline \multicolumn{13}{|l|}{ WETLAND } \\
\hline \multicolumn{13}{|l|}{ WETLAND/WETPOND } \\
\hline \multicolumn{13}{|l|}{ MAINTAINENCE PRIORITY } \\
\hline HIGH PRIORITY & 1 & 1 & 1 & 1 & 1 & 1 & 1 & 1 & 1 & 1 & 1 & 1 \\
\hline \multicolumn{13}{|l|}{ MODERATE PRIORITY } \\
\hline \multicolumn{13}{|l|}{ LOW PRIORITY } \\
\hline \multicolumn{13}{|l|}{ HYDROLOGIC DATA } \\
\hline \multicolumn{13}{|l|}{ CLOSEST ENVIORMENT RAINGUAGE } \\
\hline \multicolumn{13}{|l|}{ FROM MUNICIPALITY } \\
\hline \multicolumn{13}{|l|}{ FROM ENVIORMENT CANADA } \\
\hline \multicolumn{13}{|l|}{ PRECIPITATION RECORDS(mm) } \\
\hline HOURLY & 18.21 & 18.66 & 17.14 & 12.12 & 18.22 & 19.22 & 14.12 & 16.22 & 18.12 & 17.21 & 19.12 & 14.21 \\
\hline \multicolumn{13}{|l|}{ DAILY } \\
\hline \multicolumn{13}{|l|}{ MONTHLY } \\
\hline \multicolumn{13}{|l|}{ YEARLY } \\
\hline SNOWMELTS & $*$ & $*$ & $*$ & $*$ & $*$ & $*$ & $*$ & * & $*$ & $*$ & $*$ & $*$ \\
\hline \multicolumn{13}{|l|}{ FLOWMONITORING (m3/s) } \\
\hline FLOW MONITORING INLET & & 16.5 & & & & & & & & & & \\
\hline FLOW MONITORING OUTLET & 0.33 & 0.47 & 0.244 & 0.38 & 0.16 & 0.16 & 0.12 & 0.145 & 0.32 & 0.17 & 0.035 & 0.04 \\
\hline PONDS LEVEL MONITORING (m) & 100.62 & 100.95 & 101.55 & 101.055 & 100 & 100.9 & 100.7 & 100.42 & 100.2 & 100.9 & 100.2 & 100.21 \\
\hline WATER QUALITY MONITORING (YeS) & & & & & & & & & & & & \\
\hline
\end{tabular}




\begin{tabular}{|c|c|c|c|c|c|c|c|c|c|c|c|c|}
\hline WATER QUALITY MONITORING INLET & YES & YES & YES & YES & YES & YES & YES & YES & YES & YES & YES & YES \\
\hline WATER QUALITY MONITORING OUTLET & YES & YES & YES & YES & YES & YES & YES & YES & YES & YES & YES & YES \\
\hline \multicolumn{13}{|l|}{ FLOW MONITORING STATION } \\
\hline \multicolumn{13}{|l|}{ CATCHMENT } \\
\hline DRAINAGE AREA (HA) & 11.5 & 12.2 & 6.5 & 9.6 & 92.5 & 14.3 & 12.1 & 60.42 & 92.6 & 75.4 & 37 & 47.7 \\
\hline \multicolumn{13}{|l|}{ CATCHMENT AREA DELINEATION } \\
\hline \multicolumn{13}{|l|}{ DIGITALLY } \\
\hline \multicolumn{13}{|l|}{ MANUALLY } \\
\hline \multicolumn{13}{|l|}{ ROAD NETWORK } \\
\hline \multicolumn{13}{|l|}{ DIGITALLY } \\
\hline \multicolumn{13}{|l|}{ MANUALLY } \\
\hline \multicolumn{13}{|l|}{ STORM SEWER COLLECTION NETWORK } \\
\hline \multicolumn{13}{|l|}{ DIGITALLY } \\
\hline \multicolumn{13}{|l|}{ MANUALLY } \\
\hline \multicolumn{13}{|l|}{ IMPERVIOUS SURFACES } \\
\hline IMPERVIOUS ROOFS & * & * & * & * & $*$ & * & $*$ & * & * & * & $*$ & * \\
\hline IMPERVIOUS SIDE WALKS & * & * & $*$ & * & $*$ & * & $*$ & * & * & * & $*$ & * \\
\hline IMPERVIOUS PARKING LOTS & * & * & * & * & * & * & $*$ & * & * & * & $*$ & * \\
\hline IMPERVIOUS DRIVEWAYS & * & * & * & * & $*$ & * & $*$ & * & * & * & $*$ & * \\
\hline IMPERVIOUS AREA (m2) & * & $*$ & * & * & $*$ & * & $*$ & * & * & * & $*$ & $*$ \\
\hline \multicolumn{13}{|l|}{ LANDUSE (TOTAL IMPERVIOUSNESS \%) } \\
\hline \multicolumn{13}{|l|}{ COMMERCIAL (695 HA) } \\
\hline \multicolumn{13}{|l|}{ INDUSTRIAL (1311HA) } \\
\hline \multicolumn{13}{|l|}{ INSTITUITIONAL (644HA) } \\
\hline \multicolumn{13}{|l|}{ RESIDENTIAL (4074HA) } \\
\hline \multicolumn{13}{|l|}{ AGRICULTURE (2047HA) } \\
\hline EMPLOYMENT (OHA) & & & & & & & & & & & & \\
\hline
\end{tabular}




\begin{tabular}{|c|c|c|c|c|c|c|c|c|c|c|c|c|}
\hline MIXED USE (OHA) & & & & & & & & & & & & \\
\hline \multicolumn{13}{|l|}{ OPEN SPACE (2002HA) } \\
\hline \multicolumn{13}{|l|}{ UTILITY (158HA) } \\
\hline \multicolumn{13}{|l|}{ RECREATIONAL (515HA) } \\
\hline \multicolumn{13}{|l|}{ CATCHMENT CHANGES } \\
\hline \multicolumn{13}{|l|}{ LOW RISK } \\
\hline \multicolumn{13}{|l|}{ MEDUIM RISK } \\
\hline \multicolumn{13}{|l|}{ HIGH RISK } \\
\hline \multicolumn{13}{|l|}{ CATCHMENT PRACTICES } \\
\hline CATCH BASIN CLEANING & * & * & * & * & $*$ & * & * & * & * & * & * & * \\
\hline STREET SWEEPING & * & * & * & * & * & * & * & * & * & * & * & * \\
\hline ROAD SALTING & $*$ & $*$ & $*$ & $*$ & $*$ & $*$ & $*$ & $*$ & $*$ & $*$ & $*$ & $*$ \\
\hline \multirow{2}{*}{ ROAD SANDING PRACTICES } & * & * & * & * & * & $*$ & $*$ & * & * & * & $*$ & * \\
\hline & * & * & $*$ & * & $*$ & $*$ & $*$ & * & $*$ & $*$ & * & $*$ \\
\hline \multicolumn{13}{|l|}{ STORM WATER PONDS } \\
\hline \multicolumn{13}{|l|}{ DESIGN OF PONDS } \\
\hline AS-BUILT DRAWINGS & AVAILABLE & AVAILABLE & AVAILABLE & AVAILABLE & AVAILABLE & AVAILABLE & AVAILABLE & AVAILABLE & AVAILABLE & AVAILABLE & AVAILABLE & AVAILABLE \\
\hline \multicolumn{13}{|l|}{ INLET STRUCTURE } \\
\hline DIGITALLY & 1 & 1 & 1 & 1 & 1 & 1 & 1 & 1 & 1 & 1 & 1 & 1 \\
\hline \multicolumn{13}{|l|}{ MANUALLY } \\
\hline \multicolumn{13}{|l|}{ OUTLET STRUCTURE } \\
\hline DIGITALLY & 1 & 1 & 1 & 1 & 1 & 1 & 1 & 1 & 1 & 1 & 1 & 1 \\
\hline \multicolumn{13}{|l|}{ MANUALLY } \\
\hline \multicolumn{13}{|l|}{ PRESCENCE OF FOREBAY } \\
\hline YES & yes & yes & yes & yes & yes & yes & yes & yes & yes & yes & yes & yes \\
\hline \multicolumn{13}{|l|}{ NO } \\
\hline IMPERVIOUS AREA (\%) & 0.32 & 0.55 & 0.41 & 0.28 & 0.47 & 0.55 & 0.55 & 0.37 & 0.46 & 0.35 & 0.42 & 0.48 \\
\hline PERMANENT POOL VOLUME (m3) & 19071 & 1380 & 766 & 630 & 13245 & 1855 & 1665 & 6593 & 14652 & 11339 & 4735 & 7798 \\
\hline
\end{tabular}




\begin{tabular}{|c|c|c|c|c|c|c|c|c|c|c|c|c|}
\hline EXTENDED DETENTION REQUIREMENT (m3) & 1277 & 835 & 1699 & 1053 & 1500 & 1290 & 1680 & 1053 & 1771 & 1995 & 2080 & 1753 \\
\hline TOTAL STORAGE VOLUME (m3) & $*$ & 11000 & $*$ & 967 & 1556 & 2434 & 4027 & 6593 & 18312 & 18262 & 7050 & 19992 \\
\hline SEDIMENT LOAD REMOVED (m3/ha) & & & & 10 & & & & 36.25 & 25.8 & 19.5 & 28.9 & \\
\hline DESIGN TSS REMOVAL (\%) & 40 & 80 & 40 & 80 & 80 & 40 & 40 & 80 & 80 & 80 & 80 & 80 \\
\hline SEDIMENT VOLUME (m3) & 4745 & 584 & 123 & 750 & 1842 & 800 & N/A & 1445 & N/A & N/A & N/A & N/A \\
\hline \multicolumn{13}{|l|}{ PERCENTAGE STORAGE LOSS (\%) } \\
\hline \multicolumn{13}{|l|}{ NUMBER OF CELLS } \\
\hline LENGTH/WIDTH RATIO & 3:01 & $3: 01$ & 3:01 & 3:01 & 3:01 & 3:01 & 7:01 & $3: 01$ & 7:01 & 3:01 & 3:01 & 3:01 \\
\hline \multicolumn{13}{|l|}{ ACCUMALATED SEDIMENTS } \\
\hline \multicolumn{13}{|l|}{ SURVEYED (YES/NO) } \\
\hline YES & 1 & 1 & 1 & 1 & 1 & 1 & 1 & 1 & 1 & 1 & 1 & 1 \\
\hline \multicolumn{13}{|l|}{ NO } \\
\hline SURVEY DATES & 2011 & 2011 & 2011 & 2011 & 2011 & 2011 & N/A & N/A & N/A & N/A & N/A & N/A \\
\hline \multicolumn{13}{|l|}{ SURVEY RESULTS } \\
\hline \multicolumn{13}{|l|}{ RETROFIT } \\
\hline \multicolumn{13}{|l|}{ PLANNED } \\
\hline \multicolumn{13}{|l|}{ PREVIOUSLY } \\
\hline \multicolumn{13}{|l|}{ NOT FEASIBLE } \\
\hline \multicolumn{13}{|l|}{ YEAR RETROFIT COMPLETE } \\
\hline \multicolumn{13}{|l|}{ SEDIMENT CHARACTERIZATION } \\
\hline DIGITALLY & * & * & $*$ & $*$ & $*$ & $*$ & $*$ & $*$ & * & $*$ & $*$ & $*$ \\
\hline MANUALLY & $*$ & $*$ & $*$ & $*$ & $*$ & $*$ & $*$ & * & * & $*$ & $*$ & $*$ \\
\hline \multicolumn{13}{|l|}{ PLANTING RECORDS(YES/NO) } \\
\hline YES & yes & yes & yes & yes & yes & yes & yes & yes & yes & yes & yes & yes \\
\hline \multicolumn{13}{|l|}{ NO } \\
\hline \multicolumn{13}{|l|}{ PONDS USE FOR IRRIGATION (YES/NO) } \\
\hline YES & $*$ & * & $*$ & $*$ & $*$ & $*$ & $*$ & $*$ & $*$ & $*$ & $*$ & $*$ \\
\hline NO & * & $*$ & $*$ & $*$ & $*$ & $*$ & $*$ & $*$ & $*$ & $*$ & $*$ & $*$ \\
\hline
\end{tabular}


Municipality D

\begin{tabular}{|c|c|c|c|c|}
\hline SWM FACILITY\# & $9-3$ & $9-3$ & $9-3$ & 02-Jan \\
\hline \multicolumn{5}{|l|}{ YEAR OF CONSTRUCTION } \\
\hline \multicolumn{5}{|l|}{ TYPE OF FACILITY } \\
\hline \multicolumn{5}{|l|}{ DRY POND } \\
\hline WET POND & 2 & 2 & 2 & 2 \\
\hline \multicolumn{5}{|l|}{ WETLAND } \\
\hline \multicolumn{5}{|l|}{ WETLAND/WETPOND } \\
\hline \multicolumn{5}{|l|}{ MAINTAINENCE PRIORITY } \\
\hline HIGH PRIORITY & 1 & 1 & 1 & 1 \\
\hline \multicolumn{5}{|l|}{ MODERATE PRIORITY } \\
\hline \multicolumn{5}{|l|}{ LOW PRIORITY } \\
\hline \multicolumn{5}{|l|}{ HYDROLOGIC DATA } \\
\hline \multicolumn{5}{|l|}{ CLOSEST ENVIORMENT RAINGUAGE } \\
\hline \multicolumn{5}{|l|}{ FROM MUNICIPALITY } \\
\hline \multicolumn{5}{|l|}{ FROM ENVIORMENT CANADA } \\
\hline \multicolumn{5}{|l|}{ PRECIPITATION RECORDS(mm) } \\
\hline HOURLY & 43.3 & 43.8 & 33.6 & 41.7 \\
\hline \multicolumn{5}{|l|}{ DAILY } \\
\hline \multicolumn{5}{|l|}{ MONTHLY } \\
\hline \multicolumn{5}{|l|}{ YEARLY } \\
\hline SNOWMELTS & * & * & * & * \\
\hline \multicolumn{5}{|l|}{ FLOWMONITORING (m3/s) } \\
\hline \multicolumn{5}{|l|}{ FLOW MONITORING INLET } \\
\hline \multicolumn{5}{|l|}{ FLOW MONITORING OUTLET } \\
\hline \multicolumn{5}{|l|}{ PONDS LEVEL MONITORING (m) } \\
\hline WATER QUALITY MONITORING (Yes/No) & & & & \\
\hline
\end{tabular}




\begin{tabular}{|c|c|c|c|c|}
\hline WATER QUALITY MONITORING INLET & YES & YES & YES & YES \\
\hline WATER QUALITY MONITORING OUTLET & YES & YES & YES & YES \\
\hline \multicolumn{5}{|l|}{ FLOW MONITORING STATION } \\
\hline \multicolumn{5}{|l|}{ CATCHMENT } \\
\hline \multicolumn{5}{|l|}{ DRAINAGE AREA (HA) } \\
\hline \multicolumn{5}{|l|}{ CATCHMENT AREA DELINEATION } \\
\hline \multicolumn{5}{|l|}{ DIGITALLY } \\
\hline \multicolumn{5}{|l|}{ MANUALLY } \\
\hline \multicolumn{5}{|l|}{ ROAD NETWORK } \\
\hline \multicolumn{5}{|l|}{ DIGITALLY } \\
\hline \multicolumn{5}{|l|}{ MANUALLY } \\
\hline \multicolumn{5}{|l|}{ STORM SEWER COLLECTION NETWORK } \\
\hline \multicolumn{5}{|l|}{ DIGITALLY } \\
\hline \multicolumn{5}{|l|}{ MANUALLY } \\
\hline \multicolumn{5}{|l|}{ IMPERVIOUS SURFACES } \\
\hline IMPERVIOUS ROOFS & * & * & $*$ & * \\
\hline IMPERVIOUS SIDE WALKS & * & $*$ & $*$ & * \\
\hline IMPERVIOUS PARKING LOTS & * & * & * & $*$ \\
\hline IMPERVIOUS DRIVEWAYS & $*$ & $*$ & * & * \\
\hline IMPERVIOUS AREA (m2) & $*$ & $*$ & * & * \\
\hline \multicolumn{5}{|l|}{ LANDUSE (TOTAL IMPERVIOUSNESS \%) } \\
\hline \multicolumn{5}{|l|}{ COMMERCIAL (695 HA) } \\
\hline \multicolumn{5}{|l|}{ INDUSTRIAL (1311HA) } \\
\hline \multicolumn{5}{|l|}{ INSTITUITIONAL (644HA) } \\
\hline \multicolumn{5}{|l|}{ RESIDENTIAL (4074HA) } \\
\hline \multicolumn{5}{|l|}{ AGRICULTURE (2047HA) } \\
\hline EMPLOYMENT (OHA) & & & & \\
\hline
\end{tabular}




\begin{tabular}{|c|c|c|c|c|}
\hline MIXED USE (OHA) & & & & \\
\hline \multicolumn{5}{|l|}{ OPEN SPACE (2002HA) } \\
\hline \multicolumn{5}{|l|}{ UTILITY (158HA) } \\
\hline \multicolumn{5}{|l|}{ RECREATIONAL (515HA) } \\
\hline \multicolumn{5}{|l|}{ CATCHMENT CHANGES } \\
\hline \multicolumn{5}{|l|}{ LOW RISK } \\
\hline \multicolumn{5}{|l|}{ MEDUIM RISK } \\
\hline \multicolumn{5}{|l|}{ HIGH RISK } \\
\hline \multicolumn{5}{|l|}{ CATCHMENT PRACTICES } \\
\hline CATCH BASIN CLEANING & * & * & $*$ & * \\
\hline STREET SWEEPING & * & $*$ & $*$ & $*$ \\
\hline ROAD SALTING & $*$ & $*$ & $*$ & $*$ \\
\hline \multirow[t]{2}{*}{ ROAD SANDING PRACTICES } & $*$ & * & * & * \\
\hline & * & * & * & * \\
\hline \multicolumn{5}{|l|}{ STORM WATER PONDS } \\
\hline \multicolumn{5}{|l|}{ DESIGN OF PONDS } \\
\hline AS-BUILT DRAWINGS & AVAILABLE & AVAILABLE & AVAILABLE & AVAILABLE \\
\hline \multicolumn{5}{|l|}{ INLET STRUCTURE } \\
\hline \multicolumn{5}{|l|}{ DIGITALLY } \\
\hline \multicolumn{5}{|l|}{ MANUALLY } \\
\hline \multicolumn{5}{|l|}{ OUTLET STRUCTURE } \\
\hline \multicolumn{5}{|l|}{ DIGITALLY } \\
\hline \multicolumn{5}{|l|}{ MANUALLY } \\
\hline \multicolumn{5}{|l|}{ PRESCENCE OF FOREBAY } \\
\hline \multicolumn{5}{|l|}{ YES } \\
\hline \multicolumn{5}{|l|}{ NO } \\
\hline IMPERVIOUS AREA (\%) & 0.42 & 0.6 & 0.33 & 0.24 \\
\hline PERMANENT POOL VOLUME (m3) & 5761 & 5761 & 4641 & 1423 \\
\hline
\end{tabular}




\begin{tabular}{|c|c|c|c|c|}
\hline EXTENDED DETENTION REQUIREMENT (m3) & 295 & 295.00 & 301.5 & 1222 \\
\hline \multicolumn{5}{|l|}{ TOTAL STORAGE VOLUME (m3) } \\
\hline \multicolumn{5}{|l|}{ SEDIMENT LOAD REMOVED ( $\mathrm{m} 3 / \mathrm{ha}$ ) } \\
\hline DESIGN TSS REMOVAL (\%) & 40 & 60 & 80 & 0 \\
\hline \multicolumn{5}{|l|}{ SEDIMENT VOLUME (m3) } \\
\hline \multicolumn{5}{|l|}{ PERCENTAGE STORAGE LOSS (\%) } \\
\hline \multicolumn{5}{|l|}{ NUMBER OF CELLS } \\
\hline \multicolumn{5}{|l|}{ LENGTH/WIDTH RATIO } \\
\hline \multicolumn{5}{|l|}{ ACCUMALATED SEDIMENTS } \\
\hline \multicolumn{5}{|l|}{ SURVEYED (YES/NO) } \\
\hline YES & 1 & 1 & 1 & \\
\hline \multicolumn{5}{|l|}{ NO } \\
\hline \multicolumn{5}{|l|}{ SURVEY DATES } \\
\hline \multicolumn{5}{|l|}{ SURVEY RESULTS } \\
\hline \multicolumn{5}{|l|}{ RETROFIT } \\
\hline \multicolumn{5}{|l|}{ PLANNED } \\
\hline \multicolumn{5}{|l|}{ PREVIOUSLY } \\
\hline \multicolumn{5}{|l|}{ NOT FEASIBLE } \\
\hline \multicolumn{5}{|l|}{ YEAR RETROFIT COMPLETE } \\
\hline \multicolumn{5}{|l|}{ SEDIMENT CHARACTERIZATION } \\
\hline DIGITALLY & * & $*$ & * & $*$ \\
\hline MANUALLY & $*$ & $*$ & $*$ & $*$ \\
\hline \multicolumn{5}{|l|}{ PLANTING RECORDS(YES/NO) } \\
\hline \multicolumn{5}{|l|}{ YES } \\
\hline \multicolumn{5}{|l|}{ NO } \\
\hline \multicolumn{5}{|l|}{ PONDS USE FOR IRRIGATION (YES/NO) } \\
\hline YES & * & * & * & $*$ \\
\hline NO & * & * & * & * \\
\hline
\end{tabular}


Municipality E

\begin{tabular}{|c|c|c|c|c|c|c|c|c|c|c|c|c|c|c|c|c|c|c|c|c|c|c|c|c|c|c|c|c|c|c|}
\hline SWM FACILITY\# & 1 & 2 & 3 & 4 & 5 & 6 & 7 & 8 & 9 & 10 & 11 & 12 & 13 & 14 & 15 & 16 & 17 & 18 & 19 & 20 & 24 & 29 & 34 & 36 & 39 & 51 & 79 & 81 & 88 & 99 \\
\hline YEAR OF CONSTRUCTION & & & & & & & & & & & & & & & $\begin{array}{l}19 \\
88\end{array}$ & & & & & & $\begin{array}{l}19 \\
66\end{array}$ & & & & & & & & & \\
\hline \multicolumn{31}{|l|}{ TYPE OF FACILITY } \\
\hline \multicolumn{31}{|l|}{ DRY POND } \\
\hline WET POND & 2 & 2 & 2 & 2 & 2 & 2 & 2 & 2 & 2 & 2 & 2 & 2 & 2 & 2 & 2 & 2 & 2 & 2 & 2 & 2 & 2 & 2 & 2 & 2 & 2 & 2 & 2 & 2 & 2 & 2 \\
\hline \multicolumn{31}{|l|}{ WETLAND } \\
\hline \multicolumn{31}{|l|}{ WETLAND/WETPOND } \\
\hline \multicolumn{31}{|l|}{ MAINTAINENCE PRIORITY } \\
\hline \multicolumn{31}{|l|}{ HIGH PRIORITY } \\
\hline \multicolumn{31}{|l|}{ MODERATE PRIORITY } \\
\hline \multicolumn{31}{|l|}{ LOW PRIORITY } \\
\hline \multicolumn{31}{|l|}{ HYDROLOGIC DATA } \\
\hline \multicolumn{31}{|l|}{$\begin{array}{l}\text { CLOSEST ENVIORMENT } \\
\text { RAINGUAGE }\end{array}$} \\
\hline \multicolumn{31}{|l|}{ FROM MUNICIPALITY } \\
\hline \multicolumn{31}{|l|}{$\begin{array}{l}\text { FROM ENVIORMENT } \\
\text { CANADA }\end{array}$} \\
\hline \multicolumn{31}{|l|}{$\begin{array}{l}\text { PRECIPITATION } \\
\text { RECORDS }(\mathrm{mm})\end{array}$} \\
\hline HOURLY & $\begin{array}{l}1 \\
1 \\
. \\
2 \\
2\end{array}$ & $\begin{array}{c}13 . \\
2\end{array}$ & $\begin{array}{l}17 . \\
21\end{array}$ & $\begin{array}{l}18 \\
.1 \\
2\end{array}$ & $\begin{array}{l}19 . \\
12\end{array}$ & $\begin{array}{l}11 . \\
11\end{array}$ & $\begin{array}{l}17 \\
.1 \\
8\end{array}$ & $\begin{array}{c}18 . \\
91\end{array}$ & $\begin{array}{l}19 \\
.2 \\
2\end{array}$ & $\begin{array}{l}11 \\
.1 \\
9\end{array}$ & $\begin{array}{l}11 \\
.1 \\
2\end{array}$ & $\begin{array}{c}18 \\
.1 \\
2\end{array}$ & $\begin{array}{l}17 \\
.8\end{array}$ & $\begin{array}{c}13 . \\
6\end{array}$ & $\begin{array}{l}19 \\
.1\end{array}$ & $\begin{array}{c}16 \\
.2 \\
2\end{array}$ & $\begin{array}{l}14 . \\
18\end{array}$ & $\begin{array}{l}17 \\
.2 \\
2\end{array}$ & $\begin{array}{c}19 \\
.1 \\
1\end{array}$ & $\begin{array}{l}14 . \\
12\end{array}$ & $\begin{array}{l}19 . \\
11\end{array}$ & $\begin{array}{l}17 \\
.8\end{array}$ & $\begin{array}{c}17 . \\
2\end{array}$ & $\begin{array}{l}18 \\
.2\end{array}$ & $\begin{array}{c}19 . \\
2\end{array}$ & $\begin{array}{c}19 \\
.1 \\
1\end{array}$ & 16 & $\begin{array}{l}12 \\
.1 \\
1\end{array}$ & $\begin{array}{l}18 \\
.1 \\
2\end{array}$ & $\begin{array}{l}19 \\
.2\end{array}$ \\
\hline \multicolumn{31}{|l|}{ DAILY } \\
\hline \multicolumn{31}{|l|}{ MONTHLY } \\
\hline \multicolumn{31}{|l|}{ YEARLY } \\
\hline SNOWMELTS & $*$ & $*$ & $*$ & $*$ & $*$ & $*$ & $*$ & $*$ & $*$ & $*$ & $*$ & $*$ & $*$ & $*$ & $*$ & $*$ & $*$ & $*$ & $*$ & $*$ & $*$ & $*$ & $*$ & $*$ & $*$ & $*$ & $*$ & $*$ & $*$ & * \\
\hline \multicolumn{31}{|l|}{ FLOWMONITORING (m3/s) } \\
\hline \multicolumn{31}{|l|}{ FLOW MONITORING INLET } \\
\hline $\begin{array}{l}\text { FLOW MONITORING } \\
\text { OUTLET }\end{array}$ & $\begin{array}{l}0 \\
\dot{0} \\
0\end{array}$ & $\begin{array}{c}0.1 \\
7\end{array}$ & $\begin{array}{c}0.2 \\
2\end{array}$ & $\begin{array}{l}0 . \\
24\end{array}$ & $\begin{array}{c}0.5 \\
5\end{array}$ & $\begin{array}{l}0.0 \\
45\end{array}$ & $\begin{array}{l}0 . \\
28\end{array}$ & $\begin{array}{c}0.4 \\
4\end{array}$ & $\begin{array}{l}0 . \\
38\end{array}$ & $\begin{array}{l}0 . \\
24\end{array}$ & $\begin{array}{l}0 . \\
42\end{array}$ & $\begin{array}{l}0 . \\
42\end{array}$ & $\begin{array}{l}0 . \\
35\end{array}$ & $\begin{array}{c}0.5 \\
5\end{array}$ & $\begin{array}{l}0 . \\
04\end{array}$ & $\begin{array}{l}0 . \\
12\end{array}$ & $\begin{array}{c}0.6 \\
1\end{array}$ & $\begin{array}{l}0 . \\
22\end{array}$ & $\begin{array}{l}0 . \\
02\end{array}$ & $\begin{array}{c}0.1 \\
8\end{array}$ & $\begin{array}{c}0.3 \\
5\end{array}$ & $\begin{array}{l}0 . \\
35\end{array}$ & & & & & & & & \\
\hline
\end{tabular}




\begin{tabular}{|c|c|c|c|c|c|c|c|c|c|c|c|c|c|c|c|c|c|c|c|c|c|c|c|c|c|c|c|c|c|c|}
\hline & $\begin{array}{l}3 \\
5 \\
\end{array}$ & & & & & & & & & & & & & & & & & & & & & & & & & & & & & \\
\hline $\begin{array}{c}\text { PONDS LEVEL } \\
\text { MONITORING (m) }\end{array}$ & $\begin{array}{l}1 \\
6 \\
2 \\
. \\
4 \\
4\end{array}$ & $\begin{array}{l}128 \\
.22\end{array}$ & $\begin{array}{l}222 \\
.21\end{array}$ & $\begin{array}{c}19 \\
8 . \\
2\end{array}$ & $\begin{array}{l}199 \\
.22\end{array}$ & $\begin{array}{l}214 \\
.28\end{array}$ & $\begin{array}{c}19 \\
2\end{array}$ & $\begin{array}{l}188 \\
.22\end{array}$ & $\begin{array}{c}20 \\
4\end{array}$ & $\begin{array}{l}19 \\
6 . \\
5\end{array}$ & $\begin{array}{c}21 \\
2\end{array}$ & $\begin{array}{l}13 \\
3 . \\
4\end{array}$ & $\begin{array}{c}20 \\
1\end{array}$ & $\begin{array}{c}16 \\
2.0 \\
5\end{array}$ & $\begin{array}{c}19 \\
2\end{array}$ & $\begin{array}{c}10 \\
1\end{array}$ & $\begin{array}{c}22 \\
2.3 \\
2\end{array}$ & $\begin{array}{c}13 \\
3 . \\
4\end{array}$ & $\begin{array}{c}21 \\
2\end{array}$ & $\begin{array}{c}19 \\
1.2 \\
8\end{array}$ & $\begin{array}{c}10 \\
0.2 \\
1\end{array}$ & $\begin{array}{l}10 \\
4 . \\
2\end{array}$ & $\begin{array}{c}21 \\
2.1 \\
1\end{array}$ & $\begin{array}{c}12 \\
2\end{array}$ & $\begin{array}{c}10 \\
0.2 \\
2\end{array}$ & $\begin{array}{c}12 \\
3 . \\
1\end{array}$ & $\begin{array}{l}13 \\
1 . \\
4\end{array}$ & $\begin{array}{c}12 \\
2 . \\
4\end{array}$ & $\begin{array}{c}21 \\
2\end{array}$ & $\begin{array}{c}12 \\
2\end{array}$ \\
\hline $\begin{array}{c}\text { WATER QUALITY } \\
\text { MONITORING (Yes/No) } \\
\end{array}$ & & & & & & & & & & & & & & & & & & & & & & & & & & & & & & \\
\hline $\begin{array}{l}\text { WATER QUALITY } \\
\text { MONITORING INLET }\end{array}$ & $\begin{array}{l}\mathrm{Y} \\
\mathrm{E} \\
\mathrm{S} \\
\end{array}$ & YES & YES & $\begin{array}{c}\text { YE } \\
S\end{array}$ & YES & YES & $\begin{array}{c}\text { YE } \\
S\end{array}$ & YES & $\begin{array}{c}\text { YE } \\
S\end{array}$ & $\begin{array}{c}\text { YE } \\
S\end{array}$ & $\begin{array}{c}\text { YE } \\
S\end{array}$ & $\begin{array}{c}\text { YE } \\
S\end{array}$ & $\begin{array}{c}\text { YE } \\
S\end{array}$ & YES & $\begin{array}{c}\text { YE } \\
S\end{array}$ & $\begin{array}{c}\text { YE } \\
S\end{array}$ & YES & $\begin{array}{c}\text { YE } \\
S\end{array}$ & $\begin{array}{c}\text { YE } \\
S\end{array}$ & YES & YES & $\begin{array}{c}\text { YE } \\
S\end{array}$ & YES & $\begin{array}{c}\text { YE } \\
S\end{array}$ & YES & $\begin{array}{c}Y E \\
S\end{array}$ & $\begin{array}{l}\text { YE } \\
S\end{array}$ & $\begin{array}{c}\text { YE } \\
S\end{array}$ & $\begin{array}{c}\text { YE } \\
S\end{array}$ & $\begin{array}{c}\text { YE } \\
S\end{array}$ \\
\hline $\begin{array}{l}\text { WATER QUALITY } \\
\text { MONITORING OUTLET }\end{array}$ & $\begin{array}{l}\mathrm{Y} \\
\mathrm{E} \\
\mathrm{S} \\
\end{array}$ & YES & YES & $\begin{array}{c}\text { YE } \\
S\end{array}$ & YES & YES & $\begin{array}{c}\text { YE } \\
S\end{array}$ & YES & $\begin{array}{c}Y E \\
S\end{array}$ & $\begin{array}{c}\text { YE } \\
S\end{array}$ & $\begin{array}{c}\text { YE } \\
S\end{array}$ & $\begin{array}{c}\text { YE } \\
S\end{array}$ & $\begin{array}{c}Y E \\
S\end{array}$ & YES & $\begin{array}{c}\text { YE } \\
S\end{array}$ & $\begin{array}{c}\text { YE } \\
S\end{array}$ & YES & $\begin{array}{c}Y E \\
S\end{array}$ & $\begin{array}{c}\text { YE } \\
S\end{array}$ & YES & YES & $\begin{array}{c}\text { YE } \\
S\end{array}$ & YES & $\begin{array}{c}\text { YE } \\
S\end{array}$ & YES & $\begin{array}{c}Y E \\
S\end{array}$ & $\begin{array}{c}\text { YE } \\
S\end{array}$ & $\begin{array}{c}Y E \\
S\end{array}$ & $\begin{array}{c}\text { YE } \\
S\end{array}$ & $\begin{array}{r}\text { YE } \\
\text { S }\end{array}$ \\
\hline $\begin{array}{l}\text { FLOW MONITORING } \\
\text { STATION } \\
\end{array}$ & & & & & & & & & & & & & & & & & & & & & & & & & & & & & & \\
\hline CATCHMENT & & & & & & & & & & & & & & & & & & & & & & & & & & & & & & \\
\hline DRAINAGE AREA (HA) & $\begin{array}{l}1 \\
8 \\
0 \\
. \\
2 \\
3 \\
\end{array}$ & $\begin{array}{l}77 . \\
15\end{array}$ & $\begin{array}{l}221 \\
.54\end{array}$ & $\begin{array}{l}30 \\
.7 \\
4\end{array}$ & $\begin{array}{l}27 . \\
87\end{array}$ & $\begin{array}{l}17 . \\
64\end{array}$ & $\begin{array}{l}14 \\
.8\end{array}$ & $\begin{array}{l}29 . \\
26\end{array}$ & $\begin{array}{l}14 \\
.5\end{array}$ & $\begin{array}{l}7 . \\
56\end{array}$ & $\begin{array}{l}3 . \\
27\end{array}$ & $\begin{array}{l}2 . \\
4\end{array}$ & $\begin{array}{l}2 . \\
4\end{array}$ & $\begin{array}{c}2.1 \\
6\end{array}$ & $\begin{array}{l}3 . \\
45\end{array}$ & $\begin{array}{c}20 \\
.1 \\
2\end{array}$ & $\begin{array}{c}6.6 \\
6\end{array}$ & $\begin{array}{c}23 \\
.0 \\
6\end{array}$ & $\begin{array}{l}5 . \\
66\end{array}$ & & & & & & & & & & & \\
\hline $\begin{array}{l}\text { CATCHMENT AREA } \\
\text { DELINEATION }\end{array}$ & & & & & & & & & & & & & & & & & & & & & & & & & & & & & & \\
\hline DIGITALLY & & & & & & & & & & & & & & & & & & & & & & & & & & & & & & \\
\hline MANUALLY & & & & & & & & & & & & & & & & & & & & & & & & & & & & & & \\
\hline ROAD NETWORK & & & & & & & & & & & & & & & & & & & & & & & & & & & & & & \\
\hline DIGITALLY & & & & & & & & & & & & & & & & & & & & & & & & & & & & & & \\
\hline MANUALLY & & & & & & & & & & & & & & & & & & & & & & & & & & & & & & \\
\hline $\begin{array}{c}\text { STORM SEWER } \\
\text { COLLECTION NETWORK } \\
\end{array}$ & & & & & & & & & & & & & & & & & & & & & & & & & & & & & & \\
\hline DIGITALLY & & & & & & & & & & & & & & & & & & & & & & & & & & & & & & \\
\hline MANUALLY & & & & & & & & & & & & & & & & & & & & & & & & & & & & & & \\
\hline IMPERVIOUS SURFACES & & & & & & & & & & & & & & & & & & & & & & & & & & & & & & \\
\hline IMPERVIOUS ROOFS & $*$ & $*$ & $*$ & $*$ & $*$ & * & $*$ & $*$ & $*$ & $*$ & $*$ & $*$ & $*$ & $*$ & $*$ & $*$ & $*$ & $*$ & $*$ & $*$ & $*$ & $*$ & $*$ & $*$ & $*$ & $*$ & $*$ & $*$ & $*$ & * \\
\hline IMPERVIOUS SIDE WALKS & $*$ & $*$ & * & $*$ & $*$ & * & * & * & ${ }^{*}$ & ${ }^{*}$ & $*$ & $*$ & ${ }^{*}$ & * & ${ }^{*}$ & $*$ & $*$ & $*$ & $*$ & $*$ & * & $*$ & * & * & * & $*$ & $*$ & $*$ & $*$ & * \\
\hline $\begin{array}{l}\text { IMPERVIOUS PARKING } \\
\text { LOTS }\end{array}$ & $*$ & * & * & * & * & * & * & * & $*$ & $*$ & $*$ & $*$ & $*$ & $*$ & * & $*$ & $*$ & $*$ & $*$ & $*$ & $*$ & $*$ & $*$ & $*$ & $*$ & $*$ & $*$ & $*$ & $*$ & * \\
\hline
\end{tabular}




\begin{tabular}{|c|c|c|c|c|c|c|c|c|c|c|c|c|c|c|c|c|c|c|c|c|c|c|c|c|c|c|c|c|c|c|}
\hline IMPERVIOUS DRIVEWAYS & $*$ & $*$ & $*$ & $*$ & * & * & * & * & $*$ & * & * & * & $*$ & * & * & $*$ & * & $*$ & $*$ & $*$ & * & * & * & * & * & * & $*$ & $*$ & * & * \\
\hline IMPERVIOUS AREA (m2) & $*$ & $*$ & $*$ & $*$ & * & $*$ & $*$ & $*$ & $*$ & $*$ & $*$ & $*$ & $*$ & $*$ & $*$ & $*$ & $*$ & $*$ & $*$ & $*$ & $*$ & $*$ & $*$ & $*$ & $*$ & $*$ & $*$ & $*$ & $*$ & * \\
\hline $\begin{array}{c}\text { LANDUSE (TOTAL } \\
\text { IMPERVIOUSNESS \%) }\end{array}$ & & & & & & & & & & & & & & & & & & & & & & & & & & & & & & \\
\hline COMMERCIAL (695 HA) & & & & & & & & & & & & & & & & & & & & & & & & & & & & & & \\
\hline INDUSTRIAL (1311HA) & & & & & & & & & & & & & & & & & & & & & & & & & & & & & & \\
\hline INSTITUITIONAL (644HA) & & & & & & & & & & & & & & & & & & & & & & & & & & & & & & \\
\hline RESIDENTIAL (4074HA) & & & & & & & & & & & & & & & & & & & & & & & & & & & & & & \\
\hline AGRICULTURE (2047HA) & & & & & & & & & & & & & & & & & & & & & & & & & & & & & & \\
\hline EMPLOYMENT (OHA) & & & & & & & & & & & & & & & & & & & & & & & & & & & & & & \\
\hline MIXED USE (OHA) & & & & & & & & & & & & & & & & & & & & & & & & & & & & & & \\
\hline OPEN SPACE (2002HA) & & & & & & & & & & & & & & & & & & & & & & & & & & & & & & \\
\hline UTILITY (158HA) & & & & & & & & & & & & & & & & & & & & & & & & & & & & & & \\
\hline RECREATIONAL (515HA) & & & & & & & & & & & & & & & & & & & & & & & & & & & & & & \\
\hline CATCHMENT CHANGES & & & & & & & & & & & & & & & & & & & & & & & & & & & & & & \\
\hline LOW RISK & & & & & & & & & & & & & & & & & & & & & & & & & & & & & & \\
\hline MEDUIM RISK & & & & & & & & & & & & & & & & & & & & & & & & & & & & & & \\
\hline HIGH RISK & & & & & & & & & & & & & & & & & & & & & & & & & & & & & & \\
\hline CATCHMENT PRACTICES & & & & & & & & & & & & & & & & & & & & & & & & & & & & & & \\
\hline CATCH BASIN CLEANING & $*$ & $*$ & $*$ & $*$ & $*$ & $*$ & $*$ & $*$ & $*$ & $*$ & $*$ & * & $*$ & $*$ & $*$ & $*$ & $*$ & $*$ & * & * & $*$ & $*$ & $*$ & $*$ & $*$ & $*$ & * & $*$ & $*$ & * \\
\hline STREET SWEEPING & $*$ & $*$ & $*$ & $*$ & $*$ & $*$ & $*$ & $*$ & $*$ & $*$ & $*$ & $*$ & $*$ & $*$ & $*$ & $*$ & $*$ & $*$ & $*$ & $*$ & $*$ & $*$ & $*$ & $*$ & $*$ & $*$ & $*$ & $*$ & $*$ & $*$ \\
\hline ROAD SALTING & $*$ & $*$ & $*$ & $*$ & $*$ & $*$ & $*$ & $*$ & $*$ & $*$ & $*$ & $*$ & $*$ & $*$ & $*$ & $*$ & $*$ & $*$ & $*$ & $*$ & $*$ & $*$ & $*$ & $*$ & $*$ & $*$ & $*$ & $*$ & $*$ & $*$ \\
\hline ROAD SANDING PRACTICES & $*$ & $*$ & $*$ & $*$ & * & $*$ & $*$ & $*$ & $*$ & * & $*$ & $*$ & $*$ & $*$ & $*$ & $*$ & $*$ & $*$ & $*$ & * & $*$ & $*$ & $*$ & $*$ & $*$ & $*$ & $*$ & $*$ & * & * \\
\hline & $*$ & $*$ & $*$ & $*$ & * & $*$ & $*$ & $*$ & $*$ & $*$ & $*$ & * & $*$ & $*$ & $*$ & $*$ & $*$ & $*$ & * & * & $*$ & $*$ & $*$ & $*$ & $*$ & $*$ & $*$ & $*$ & * & * \\
\hline STORM WATER PONDS & & & & & & & & & & & & & & & & & & & & & & & & & & & & & & \\
\hline DESIGN OF PONDS & & & & & & & & & & & & & & & & & & & & & & & & & & & & & & \\
\hline AS-BUILT DRAWINGS & & & & & & & & & & & & & & & & & & & & & & & & & & & & & & \\
\hline INLET STRUCTURE & & & & & & & & & & & & & & & & & & & & & & & & & & & & & & \\
\hline DIGITALLY & & & & & & & & & & & & & & & & & & & & & & & & & & & & & & \\
\hline
\end{tabular}




\begin{tabular}{|c|c|c|c|c|c|c|c|c|c|c|c|c|c|c|c|c|c|c|c|c|c|c|c|c|c|c|c|c|c|c|}
\hline MANUALLY & & & & & & & & & & & & & & & & & & & & & & & & & & & & & & \\
\hline OUTLET STRUCTURE & & & & & & & & & & & & & & & & & & & & & & & & & & & & & & \\
\hline DIGITALLY & & & & & & & & & & & & & & & & & & & & & & & & & & & & & & \\
\hline MANUALLY & & & & & & & & & & & & & & & & & & & & & & & & & & & & & & \\
\hline PRESCENCE OF FOREBAY & & & & & & & & & & & & & & & & & & & & & & & & & & & & & & \\
\hline YES & & & & & & & & & & & & & & & & & & & & & & & & & & & & & & \\
\hline NO & & & & & & & & & & & & & & & & & & & & & & & & & & & & & & \\
\hline IMPERVIOUS AREA (\%) & $\begin{array}{l}0 \\
3 \\
3\end{array}$ & $\begin{array}{c}0.6 \\
5\end{array}$ & 0.4 & $\begin{array}{l}0 . \\
3\end{array}$ & 0.4 & 0.4 & $\begin{array}{l}0 . \\
4\end{array}$ & 0.4 & $\begin{array}{l}0 . \\
4\end{array}$ & $\begin{array}{l}0 . \\
4\end{array}$ & $\begin{array}{l}0 . \\
4\end{array}$ & $\begin{array}{c}0 . \\
4\end{array}$ & $\begin{array}{l}0 . \\
4\end{array}$ & $\begin{array}{c}0.9 \\
5\end{array}$ & $\begin{array}{l}0 . \\
4\end{array}$ & $\begin{array}{c}0 . \\
3\end{array}$ & $\begin{array}{c}0.6 \\
5\end{array}$ & $\begin{array}{l}0 . \\
4\end{array}$ & $\begin{array}{l}0 . \\
4\end{array}$ & 0.4 & 0.4 & $\begin{array}{l}0 . \\
4\end{array}$ & 0.4 & $\begin{array}{l}0 . \\
4\end{array}$ & 0.4 & $\begin{array}{l}0 . \\
3\end{array}$ & $\begin{array}{l}0 . \\
6\end{array}$ & $\begin{array}{l}0 . \\
4\end{array}$ & $\begin{array}{l}0 . \\
4\end{array}$ & $\begin{array}{l}0 . \\
4\end{array}$ \\
\hline $\begin{array}{l}\text { PERMANENT POOL } \\
\text { VOLUME (m3) }\end{array}$ & $\begin{array}{l}1 \\
2 \\
5 \\
9 \\
5\end{array}$ & $\begin{array}{c}137 \\
39\end{array}$ & $\begin{array}{c}760 \\
0\end{array}$ & $\begin{array}{c}95 \\
1\end{array}$ & $\begin{array}{c}250 \\
4\end{array}$ & 796 & $\begin{array}{l}19 \\
88\end{array}$ & $\begin{array}{c}139 \\
1\end{array}$ & $\begin{array}{c}98 \\
3\end{array}$ & $\begin{array}{c}34 \\
4\end{array}$ & $\begin{array}{l}16 \\
68\end{array}$ & $*$ & * & * & $*$ & 72 & * & $*$ & $*$ & * & & & & & & & & & & \\
\hline $\begin{array}{l}\text { EXTENDED DETENTION } \\
\text { REQUIREMENT }(\mathrm{m} 3)\end{array}$ & $\begin{array}{l}1 \\
0 \\
1 \\
3\end{array}$ & $\begin{array}{c}323 \\
9\end{array}$ & * & $\begin{array}{l}12 \\
80\end{array}$ & $\begin{array}{c}247 \\
1\end{array}$ & 613 & $\begin{array}{c}67 \\
3\end{array}$ & $\begin{array}{c}206 \\
5\end{array}$ & $\begin{array}{c}57 \\
3\end{array}$ & $\begin{array}{c}28 \\
1\end{array}$ & $\begin{array}{l}20 \\
44\end{array}$ & $*$ & * & * & 55 & * & * & * & $*$ & * & & & & & & & & & & \\
\hline $\begin{array}{c}\text { TOTAL STORAGE VOLUME } \\
\text { (m3) }\end{array}$ & & & & & & & & & & & & & & & & & & & & & & & & & & & & & & \\
\hline $\begin{array}{l}\text { SEDIMENT LOAD REMOVED } \\
(\mathrm{m} / \mathrm{ha})\end{array}$ & & & & & & & & & & 0 & & & & & & & & & & $\begin{array}{c}12 \\
6 \\
\end{array}$ & & $\begin{array}{c}57 \\
3 \\
\end{array}$ & $\begin{array}{c}11 \\
9 \\
\end{array}$ & $\begin{array}{c}24 \\
8 \\
\end{array}$ & 30 & $\begin{array}{c}17 \\
4 \\
\end{array}$ & $\begin{array}{c}11 \\
2 \\
\end{array}$ & $\begin{array}{c}13 \\
7 \\
\end{array}$ & $\begin{array}{c}76 \\
6 \\
\end{array}$ & $\begin{array}{c}51 \\
7 \\
\end{array}$ \\
\hline DESIGN TSS REMOVAL (\%) & 0 & 80 & 40 & 40 & 40 & 40 & 40 & 40 & 60 & 60 & 80 & 80 & 60 & 40 & 0 & 0 & 40 & 0 & 60 & 40 & & & & & & & & & & \\
\hline SEDIMENT VOLUME (m3) & & & & & & & & & & & & & & & & & & & & & & & & & & & & & & \\
\hline $\begin{array}{l}\text { PERCENTAGE STORAGE } \\
\text { LOSS (\%) }\end{array}$ & $\begin{array}{l}1 \\
4 \\
3 \\
9 \\
9\end{array}$ & $\begin{array}{c}78 . \\
86\end{array}$ & $\begin{array}{c}67 . \\
6\end{array}$ & $\begin{array}{l}28 \\
.2\end{array}$ & $\begin{array}{l}22 . \\
25\end{array}$ & $\begin{array}{l}17 . \\
22\end{array}$ & $\begin{array}{l}14 \\
.8\end{array}$ & $\begin{array}{l}12 . \\
37\end{array}$ & $\begin{array}{l}8 . \\
74\end{array}$ & $\begin{array}{l}7 . \\
01\end{array}$ & $\begin{array}{l}3 . \\
27\end{array}$ & $\begin{array}{l}2 . \\
4\end{array}$ & $\begin{array}{l}2 . \\
4\end{array}$ & $\begin{array}{c}2.1 \\
6\end{array}$ & $\begin{array}{l}1 . \\
37\end{array}$ & * & * & $*$ & $*$ & * & & & & & & & & & & \\
\hline NUMBER OF CELLS & & & & & & & & & & & & & & & & & & & & & & & & & & & & & & \\
\hline LENGTH/WIDTH RATIO & * & * & * & $*$ & $*$ & $*$ & $*$ & $*$ & $*$ & $*$ & $*$ & $*$ & * & $*$ & $*$ & $*$ & * & $*$ & $*$ & $*$ & $*$ & $*$ & $*$ & $*$ & $*$ & $*$ & $*$ & * & $*$ & $*$ \\
\hline $\begin{array}{l}\text { ACCUMALATED } \\
\text { SEDIMENTS } \\
\end{array}$ & & & & & & & & & & & & & & & & & & & & & & & & & & & & & & \\
\hline SURVEYED (YES/NO) & & & & & & & & & & & & & & & & & & & & & & & & & & & & & & \\
\hline YES & & & & & & & & & & & & & & & & & & & & & & & & & & & & & & \\
\hline NO & & & & & & & & & & & & & & & & & & & & & & & & & & & & & & \\
\hline SURVEY DATES & $\begin{array}{l}2 \\
0 \\
1 \\
4\end{array}$ & $\begin{array}{c}201 \\
4\end{array}$ & $\begin{array}{c}201 \\
4\end{array}$ & $\begin{array}{l}20 \\
14\end{array}$ & $\begin{array}{c}201 \\
4\end{array}$ & $\begin{array}{c}201 \\
4\end{array}$ & $\begin{array}{l}20 \\
14\end{array}$ & $\begin{array}{c}201 \\
4\end{array}$ & $\begin{array}{l}20 \\
14\end{array}$ & $\begin{array}{l}20 \\
14\end{array}$ & $\begin{array}{l}20 \\
14\end{array}$ & $\begin{array}{l}20 \\
14\end{array}$ & $\begin{array}{l}20 \\
14\end{array}$ & $\begin{array}{l}20 \\
14\end{array}$ & $\begin{array}{l}20 \\
14\end{array}$ & $\begin{array}{l}20 \\
14\end{array}$ & $\begin{array}{l}20 \\
14\end{array}$ & $\begin{array}{l}20 \\
14\end{array}$ & $\begin{array}{l}20 \\
14\end{array}$ & $\begin{array}{l}20 \\
14\end{array}$ & $\begin{array}{l}20 \\
14\end{array}$ & $\begin{array}{l}20 \\
14\end{array}$ & $\begin{array}{l}20 \\
14\end{array}$ & $\begin{array}{l}20 \\
14\end{array}$ & $\begin{array}{l}20 \\
14\end{array}$ & $\begin{array}{l}20 \\
14\end{array}$ & $\begin{array}{l}20 \\
14\end{array}$ & $\begin{array}{l}20 \\
14\end{array}$ & $\begin{array}{l}20 \\
14\end{array}$ & $\begin{array}{l}20 \\
14\end{array}$ \\
\hline
\end{tabular}




\begin{tabular}{|c|c|c|c|c|c|c|c|c|c|c|c|c|c|c|c|c|c|c|c|c|c|c|c|c|c|c|c|c|c|c|}
\hline SURVEY RESULTS & & & & & & & & & & & & & & & & & & & & & & & & & & & & & & \\
\hline RETROFIT & & & & & & & & & & & & & & & & & & & & & & & & & & & & & & \\
\hline PLANNED & & & & & & & & & & & & & & & & & & & & & & & & & & & & & & \\
\hline PREVIOUSLY & & & & & & & & & & & & & & & & & & & & & & & & & & & & & & \\
\hline NOT FEASIBLE & & & & & & & & & & & & & & & & & & & & & & & & & & & & & & \\
\hline YEAR RETROFIT COMPLETE & $\begin{array}{l}2 \\
0 \\
1 \\
4 \\
\end{array}$ & $\begin{array}{c}201 \\
0\end{array}$ & $\begin{array}{c}201 \\
0\end{array}$ & $\begin{array}{l}20 \\
10\end{array}$ & $\begin{array}{c}201 \\
5\end{array}$ & $\begin{array}{c}201 \\
4\end{array}$ & $\begin{array}{l}20 \\
11\end{array}$ & $\begin{array}{c}201 \\
1\end{array}$ & $\begin{array}{l}20 \\
10\end{array}$ & $\begin{array}{l}20 \\
11\end{array}$ & $\begin{array}{l}20 \\
10\end{array}$ & $\begin{array}{l}20 \\
15\end{array}$ & $\begin{array}{l}20 \\
11\end{array}$ & $\begin{array}{l}20 \\
11\end{array}$ & $\begin{array}{l}20 \\
13\end{array}$ & $\begin{array}{l}20 \\
13\end{array}$ & $\begin{array}{l}20 \\
14\end{array}$ & $\begin{array}{l}20 \\
13\end{array}$ & $\begin{array}{l}20 \\
13\end{array}$ & $\begin{array}{l}20 \\
15\end{array}$ & $\begin{array}{l}20 \\
09\end{array}$ & $\begin{array}{l}20 \\
10\end{array}$ & $\begin{array}{l}20 \\
15\end{array}$ & $\begin{array}{l}20 \\
11\end{array}$ & $\begin{array}{l}20 \\
10\end{array}$ & $\begin{array}{l}20 \\
09\end{array}$ & $\begin{array}{l}20 \\
16\end{array}$ & $\begin{array}{l}20 \\
16\end{array}$ & $\begin{array}{l}20 \\
15\end{array}$ & $\begin{array}{l}20 \\
15\end{array}$ \\
\hline $\begin{array}{c}\text { SEDIMENT } \\
\text { CHARACTERIZATION }\end{array}$ & & & & & & & & & & & & & & & & & & & & & & & & & & & & & & \\
\hline DIGITALLY & $*$ & * & * & $*$ & $*$ & * & $*$ & * & $*$ & $*$ & $*$ & $*$ & $*$ & * & $*$ & $*$ & $*$ & $*$ & * & * & $*$ & $*$ & $*$ & $*$ & $*$ & $*$ & $*$ & $*$ & $*$ & * \\
\hline MANUALLY & $*$ & * & * & $*$ & $*$ & * & $*$ & * & $*$ & $*$ & $*$ & $*$ & $*$ & $*$ & $*$ & $*$ & $*$ & $*$ & $*$ & $*$ & $*$ & $*$ & $*$ & $*$ & $*$ & $*$ & $*$ & $*$ & $*$ & * \\
\hline $\begin{array}{c}\text { PLANTING } \\
\text { RECORDS(YES/NO) } \\
\end{array}$ & & & & & & & & & & & & & & & & & & & & & & & & & & & & & & \\
\hline YES & & & & & & & & & & & & & & & & & & & & & & & & & & & & & & \\
\hline NO & & & & & & & & & & & & & & & & & & & & & & & & & & & & & & \\
\hline $\begin{array}{c}\text { PONDS USE FOR } \\
\text { IRRIGATION (YES/NO) } \\
\end{array}$ & & & & & & & & & & & & & & & & & & & & & & & & & & & & & & \\
\hline YES & $*$ & * & * & $*$ & * & * & $*$ & * & $*$ & $*$ & $*$ & $*$ & $*$ & $*$ & $*$ & $*$ & $*$ & $*$ & $*$ & $*$ & $*$ & $*$ & $*$ & $*$ & $*$ & $*$ & $*$ & $*$ & $*$ & * \\
\hline NO & $*$ & $*$ & * & $*$ & $*$ & * & $*$ & * & $*$ & $*$ & $*$ & * & $*$ & $*$ & $*$ & $*$ & $*$ & $*$ & * & * & $*$ & $*$ & $*$ & $*$ & $*$ & $*$ & $*$ & $*$ & $*$ & * \\
\hline
\end{tabular}


Appendix B - Sediment Accumulation Rate Calculations

\begin{tabular}{|c|c|c|c|}
\hline YEAR & DRAINAGE AREA (HA) & SEDIMENT VOLUME(m3) & $\begin{array}{c}\text { SEDIMENT ACCUMULATION } \\
\text { RATES (m3 } \\
\text { /ha/year) }\end{array}$ \\
\hline 2010 & 29 & & 0 \\
\hline 1998 & 20.87 & 190 & 9.1 \\
\hline 1990 & 31.4 & & 0 \\
\hline 2010 & 33.29 & & 0 \\
\hline 2003 & 45.3 & 169 & 3.7 \\
\hline 2013 & 32 & & 0 \\
\hline 1994 & 11.2 & & 0 \\
\hline 1994 & 21 & 180 & 8.5 \\
\hline 1995 & 4.1 & & 0 \\
\hline 1997 & 4 & & 0 \\
\hline 1995 & 55.8 & 350 & 6.2 \\
\hline 1996 & 12.05 & & 0 \\
\hline 1997 & 31 & & 0 \\
\hline 2009 & 56 & 364 & 6.5 \\
\hline 1998 & 21.65 & 101 & 4.6 \\
\hline 1995 & 2.83 & & 0 \\
\hline 1983 & 600 & & 0 \\
\hline 1983 & 0 & 0 & 0 \\
\hline 2006 & 25.6 & 130 & 5.0 \\
\hline 2005 & 23.2 & 190 & 8.5 \\
\hline 2007 & 40 & 203 & 5.0 \\
\hline 2002 & 25.49 & 150 & 5.8 \\
\hline 1999 & 17.8 & 150 & 8.4 \\
\hline 1999 & 32.9 & 240 & 7.2 \\
\hline 1999 & 60 & & 0 \\
\hline
\end{tabular}




\begin{tabular}{|c|c|c|c|}
\hline 2003 & 22 & 170 & 7.7 \\
\hline 1989 & 7.64 & & 0 \\
\hline 2005 & 70.1 & & 0 \\
\hline 2008 & 32.46 & 269 & 8.2 \\
\hline 2005 & 36.28 & 132 & 3.6 \\
\hline 1999 & 24.2 & 105 & 4.3 \\
\hline 2006 & 20.6 & 122 & 5.9 \\
\hline 2005 & 20.35 & 0 & 0 \\
\hline 2004 & 17.4 & & 0 \\
\hline 2006 & 21.4 & 212 & 9.9 \\
\hline 2002 & 23.2 & 144 & 6.2 \\
\hline 2013 & 18.6 & 160 & 8.6 \\
\hline 1999 & 30.77 & 295 & 9.5 \\
\hline 1999 & 19.47 & 74 & 3.8 \\
\hline 1991 & 28.65 & 124 & 4.3 \\
\hline 1990 & 35.94 & 144 & 4.0 \\
\hline 2000 & 18.46 & 148 & 8.0 \\
\hline 1993 & 0 & 323 & 0 \\
\hline 2012 & 25.18 & 115 & 4.5 \\
\hline 2008 & 35.48 & 288 & 8.1 \\
\hline 2008 & 14.72 & 38 & 2.5 \\
\hline 2010 & 41.08 & 395 & 9.6 \\
\hline 2009 & 35.34 & & 0 \\
\hline 2012 & 31.84 & 168 & 5.2 \\
\hline 1994 & 16.31 & & 0 \\
\hline 1999 & 21.5 & 145 & 6.7 \\
\hline 1994 & 22.2 & 184 & 8.2 \\
\hline 1999 & 16.5 & 123 & 7.4 \\
\hline 1997 & 29.6 & 150 & 5.0 \\
\hline 1997 & 20.5 & 184 & 8.9 \\
\hline 2012 & 14.3 & 80 & 5.5 \\
\hline 2010 & 12.1 & & 0 \\
\hline 2008 & 60.42 & 144 & 2.3 \\
\hline
\end{tabular}




\section{REFERENCES}

Arvind, N., \& Pitt, R. (2006). Costs of Urban Stormwater Control Practices. Alabama. Barry, C., \& Megan, S. (n.d.). Urban Stormwater Guidelines and best management Practices for protection of fish and fish habitat. Fisheries and ocean Canada.

Chilibeck, B. (May 1992, MAY). Land Development Guidelines for the Protection of Aquatic Habitat.

Christopher C. Obropta, J. S. (2007). Review of Urban Stormwater Quality Models: Deterministic, Stochastic, and Hybrid Approaches. The Journal of the American Water Resources Association (JAWRA), 1508-1523.

Christopher, C., \& Josef, S. (2007). Review of Urban Stormwater Quality Models: Deterministic, Stochastic, and Hybrid Approaches $\dagger$. The American Water resource Association, 1508-1523.

Coles, J. (2012). Effects of urban development on stream ecosystems across the United States. USGS Science of changing world.

commission, P. a. (2012). Stormwater Monitoring Guidelines North of Dundas Street. Oakville: Development Engineering Department.

Committee, V. S. (1999). Urban Stormwater: Best-Practice Environmental Management Guidelines. Csiro Publishing.

Credit Valley Conservation Ontario. (2010). Low impact development Planning and design Guide. Toronto and Region Conservation Authority.

Ellis, J. B. (1999). Impacts of Urban Growth on Surface Water and Groundwater Quality. IAHS.

Fairchild, A. B. (2012). Sediment characteristics and accumulation rates in constructed ponds.

Frederic , T., \& Laffont,S. (2009, june). Heavy Metal Lability in Porewater of Highway Detention Pond Sediments in South-Eastern France in Relation to Submerged Vegetation. Water, Air, \& Soil Pollution, 229-240.

G Droppo, E Walling, D., \& Ongley, E. (1998, JULY). Suspended sediment structure: implications for sediment and contaminant transport modelling.

Glenn, R., \& Doug, S. (1994). B-1-5 Deriving Receiving Water Based Point Source Effluent Requirements for Ontario Waters. Ministry of the Environment and Energy staff.

Gollan, N. (2016). City of Kitchener Integrated Stormwater Management Master Plan (ISWM$M P)$. kitchener.

Greenland International Consulting Inc. (1999). Stormwater Management Facility sediment maintenance Guidance.

Gregory, M. (2014). Stormwater Pond Sediment Loading and Accumulation Analysis. Journal of water Management Modelling.

Guo, J. D. (10 December 2016,). Maintenance of Wet Stormwater Ponds in Ontario. Hajnal, P. I. (1994). International Information: Documents, Publications, and Electronic. Hogan \& Walbridge, M. R. (2007). Urbanization and Nutrient Retention in Freshwater Riparian Wetlands. Ecological Applications (Ecological Society of America), 11421155. 
Howarth, R. (1996). Nitrogen Cycling in the North Atlantic Ocean and its Watersheds. kluwer Academic Publisher.

J.Marsalek, \& P.M Marsalek. (1997). Characteristics of sediments from a stormwater management pond. In water science and technology (pp. 117-122). IWA Publisher.

Jacobsen, T. (1994). Treatment Systems for Urban and Highway Run-off in Denmark. In Science of The Total Environment (p. 506). Elsevier B.V.

Jesper Persson, N. S. (2006). Hydraulics efficiency of constructed wetlands and ponds. IWA Publishing.

Jesper Persson, N. S. (2006). Hydraulics efficiency of constructed wetlands and ponds. IWA Publishing.

Lu, C. j. (2016). The Status of Pollutants in the Three Gorges Reservoir Area,China and its Ecological Health Assessment. American Journal of Environmental Sciences, 317-327.

Lubis, A. A. (2006, may 11). CONSTANT RATE OF SUPPLY (CRS) MODEL FOR DETERMINING THE SEDIMENT ACCUMULATION RATES IN THE COASTAL AREA USING 210Pb.

M Sivakumar, \& D.May. (2009). Optimum number of storms required to derive site mean concentrations at urban catchments. Urban water journel, 113.

Ministry of Environment. (2003). Stormwater Management Planning and Design Manual.

Mitchell, P. (2010). Sediment Accumulation Monitoring Techniques. Newzealand: Aukland Motorways.

MOECC. (2003). Stormwater Management Planning and Design Manual. Ministry of the Environment. National guide to Sustainable Municipal Structure.

Murray, G. (March 2003). Stormwater management planning and design manual.

Muthukrishnan, S. $(2010,11)$. Treatment Of Heavy Metals In Stormwater Runoff Using Wet Pond And Wetland Mesocosms. Annual International Conference on Soils Vol. 11, Article 9., (p. 139).

Nittrouer, C. (1986). Concentration and flux of suspended sediment on the Amazon continental shelf. In T. C. C.A. Nittrouer, Concentration and flux of suspended sediment on the Amazon continental shelf (p. 174). Continental Shelf Research.

Randolph, J. (2003). Environmental Land Use Planning and Management. In J. Randolph, Environmental Land Use Planning and Management, 3rd ed. edition (p. 704). Island Press.

Richard, R. (2010). Investigation of Sediment removal frequency for Wet Detention Stormwater mnanagement Ponds. Toronto: ryerson university.

Rishon, R. (2010). Investigation of the Sediment removal frequency for Wet-Detention Stormwater management Ponds. TORONTO: Rishon Richard.

Robert Abrahart, P. K. (2004). Neural Networks for Hydrological Modeling. CRC Press.

Simon, R. E. (5 March 2006). Temporal trends of trace metals in sediment and invertebrates from stormwater management ponds.

(2008). Stormwater Management Facility inventory, Assessment and maintenance needs plan Final report. Guelph: Engineers Architects Planners.

(March 2003). Stormwater Management Planning and Design Manual.

(2009). Stormwater Wet Pond and wetland management Guide book. EPA.

US Environmental Protection Agency. (1998, may 14). Guidelines for Ecological Risk Assessment. Washington, DC: National Service Center for Environmental Publications (NSCEP). 
US Environmental Protection Agency. (2003). Protecting Water quality in Urban runoff. Environment Protection Agency.

Wanielista, M. P., \& Yousef, Y. A. (1992). Stormwater Management. In Y. A. Martin P. Wanielista, Stormwater Management 1st Edition (p. 528). Wiley-Interscience.

Westerbeek Vopicka, K. (2009). Sediment Assessment of Stormwater Retention Ponds within the Urban Environment of Calgary, Canada. Water Quality Research Journal of Canada, 11.

Zalewska, T. (2014). Sediment deposition and accumulation rates determined by sediment trap and 210Pb isotope methods in the Outer Puck Bay. Oceanologia, 85-106. 